\title{
Market Timing and Capital Structure
}

\author{
MALCOLM BAKER and JEFFREY WURGLER*
}

\begin{abstract}
It is well known that firms are more likely to issue equity when their market values are high, relative to book and past market values, and to repurchase equity when their market values are low. We document that the resulting effects on capital structure are very persistent. As a consequence, current capital structure is strongly related to historical market values. The results suggest the theory that capital structure is the cumulative outcome of past attempts to time the equity market.
\end{abstract}

IN CORPORATE FINANCE, "equity market timing" refers to the practice of issuing shares at high prices and repurchasing at low prices. The intention is to exploit temporary fluctuations in the cost of equity relative to the cost of other forms of capital. In the efficient and integrated capital markets studied by Modigliani and Miller (1958), the costs of different forms of capital do not vary independently, so there is no gain from opportunistically switching between equity and debt. In capital markets that are inefficient or segmented, by contrast, market timing benefits ongoing shareholders at the expense of entering and exiting ones. Managers thus have incentives to time the market if they think it is possible and if they care more about ongoing shareholders.

In practice, equity market timing appears to be an important aspect of real corporate financial policy. There is evidence for market timing in four different kinds of studies. First, analyses of actual financing decisions show that firms tend to issue equity instead of debt when market value is high, relative to book value and past market values, and tend to repurchase equity when market value is low. ${ }^{1}$ Second, analyses of long-run stock returns fol-

\footnotetext{
* Baker is from the Harvard University Graduate School of Business Administration. Wurgler is from the New York University Stern School of Business. We thank Arturo Bris, John Campbell, Paul Gompers, Roger Ibbotson, Andrew Roper, Geert Rouwenhorst, Geoff Verter, Ralph Walkling, participants of seminars at Columbia, Cornell, Duke, Harvard, INSEAD, MIT, Northwestern, NYU, Rutgers, Stanford, University of Chicago, University of North Carolina at Chapel Hill, University of Notre Dame, Wharton, and Yale, and especially Richard Green, Andrei Shleifer, Jeremy Stein, Ivo Welch, and an anonymous referee for helpful comments. We thank John Graham and Jay Ritter for data and Alok Kumar for research assistance. Baker gratefully acknowledges the financial support of the Division of Research of the Harvard Graduate School of Business Administration.

${ }^{1}$ Seasoned equity issues coincide with high valuations in Taggart (1977), Marsh (1982), Asquith and Mullins (1986), Korajczyk, Lucas, and McDonald (1991), Jung, Kim, and Stulz (1996), and Hovakimian, Opler, and Titman (2001). Initial public equity issues coincide with high valuations in Loughran, Ritter, and Rydqvist (1994) and Pagano, Panetta, and Zingales (1998). Repurchases coincide with low valuations in Ikenberry, Lakonishok, and Vermaelen (1995).
} 
lowing corporate finance decisions suggest that equity market timing is successful on average. Firms issue equity when the cost of equity is relatively low and repurchase equity when the cost is relatively high. ${ }^{2}$ Third, analyses of earnings forecasts and realizations around equity issues suggest that firms tend to issue equity at times when investors are rather too enthusiastic about earnings prospects. ${ }^{3}$ Fourth, and perhaps most convincing, managers admit to market timing in anonymous surveys. Graham and Harvey (2001) find that two-thirds of CFOs agree that "the amount by which our stock is undervalued or overvalued was an important or very important consideration" in issuing equity, and nearly as many agree that "if our stock price has recently risen, the price at which we can sell is 'high"' (p. 216). In that survey as a whole, equity market prices are regarded as more important than 9 out of 10 other factors considered in the decision to issue common stock, and more important than all 4 other factors considered in the decision to issue convertible debt.

In this paper, we ask how equity market timing affects capital structure. The basic question is whether market timing has a short-run or a long-run impact. One expects at least a mechanical, short-run impact. However, if firms subsequently rebalance away the influence of market timing financing decisions, as normative capital structure theory recommends, then market timing would have no persistent impact on capital structure. The significance of market timing for capital structure is therefore an empirical issue.

Our results are consistent with the hypothesis that market timing has large, persistent effects on capital structure. The main finding is that low leverage firms are those that raised funds when their market valuations were high, as measured by the market-to-book ratio, while high leverage firms are those that raised funds when their market valuations were low. We document this in traditional capital structure regressions. Leverage is the dependent variable and the "external finance weighted-average" marketto-book ratio is the independent variable. This variable is a weighted average of a firm's past market-to-book ratios which, for example, takes high values for firms that raised their external finance-equity or debt-when their marketto-book ratios were high. The basic regression result is that leverage is strongly negatively related to this measure of historical market valuations.

\footnotetext{
${ }^{2}$ Net of adverse announcement effects, equity issuers have low subsequent (idiosyncratic) returns in Stigler (1964), Ritter (1991), Loughran and Ritter (1995), Speiss and Affleck-Graves (1995), Brav and Gompers (1997), and Jegadeesh (2000), and high market-to-book issuers earn even lower returns. Repurchasers have high (idiosyncratic) returns in Ikenberry et al. (1995), and low market-to-book repurchasers earn even higher returns. Not all authors interpret these results as successful market timing: Eckbo, Masulis, and Norli (2000) interpret the firm-level results as reflecting low risk of equity issuers, and Fama (1998) challenges the firm-level results on several grounds. A high share of equity issues in aggregate equity and debt issues also forecasts low (market) returns in Baker and Wurgler (2000). This market-level evidence goes the same direction as the firm-level evidence and avoids some of the methodological difficulties endemic to the firm-level studies.

${ }^{3}$ See Loughran and Ritter (1997), Rajan and Servaes (1997), Teoh, Welch, and Wong (1998a, 1998b), and Denis and Sarin (2001).
} 
The influence of past market valuations on capital structure is economically significant and statistically robust. The relationship is apparent whether leverage is measured in book or market values or whether various control variables are included. The influence of past market valuations on capital structure is also quite persistent. We document this persistence in three separate ways. A first test uses leverage regressions that control for the current market-to-book. This leaves the weighted average to pick up only the within-firm time-series variation. The fact that this variation helps to explain capital structure outcomes implies that temporary fluctuations in market valuations can lead to permanent changes in capital structure. A second test for persistence is in regressions that control for the initial capital structure level and look at how subsequent fluctuations in market valuations move capital structure away from this initial level. A third test for persistence is to look at the power of lagged values of the weighted average market-to-book variable. The impact of past market values turns out to have a half-life of well over 10 years. For example, capital structure as of the year 2000 depends strongly upon variation in the market-to-book ratio from 1990 and before, even controlling for the 1999 value of market-to-book.

The bottom line is that fluctuations in market value have very long-run impacts on capital structure. It is hard to explain this result within traditional theories of capital structure. In the trade-off theory, market-to-book is an indicator of investment opportunities, risk, agency, or some other determinant of the optimal leverage ratio. The trade-off theory predicts that temporary fluctuations in the market-to-book ratio or any other variable should have temporary effects. The evidence indicates that the market-to-book ratio has very persistent effects, however. In the pecking order theory of Myers (1984), adverse selection leads managers to avoid issuing equity entirely. A dynamic version predicts that firms with upcoming investment opportunities may reduce leverage to avoid issuing equity in the future. Nevertheless, it is hard to imagine a version of the pecking order theory that explains the observed strong relationship between leverage and the long-past pattern of investment opportunities. The standard version implies that periods of high investment will push leverage higher toward a debt capacity, not lower as our results suggest. In the managerial entrenchment theory of capital structure in Zwiebel (1996), high market valuations allow managers to add equity but also allow them to become entrenched, resisting the debt finance necessary to restore debt to the optimum. While generally consistent with our evidence, this theory has managers exploiting existing investors ex post by not rebalancing with debt. The prior studies of earnings management evidence and long-run returns suggest that managers aim to exploit new investors.

In our opinion, a simple and realistic explanation for the results is that capital structure is the cumulative outcome of attempts to time the equity market. This is a simple theory of capital structure. To our knowledge, it has not been articulated before.

There are two versions of equity market timing that could be behind our results. One is a dynamic version of Myers and Majluf (1984) with rational 
managers and investors. The extent of adverse selection varies across firms or across time and is inversely related to the market-to-book ratio. The second version is that managers think investors are irrational and raise equity when the cost of equity is unusually low. This story explains the results if variation in the market-to-book ratio is a proxy for managers' perceptions of misvaluation. To explain the persistent empirical effect of past valuations, both versions require that adjustment costs, perhaps related to adverse selection, reduce the desirability of undoing market timing. Our results do not discriminate between these two versions of market timing, but the earnings management evidence and the long-run return evidence points to the second.

The rest of the paper is organized as follows. Section I investigates the relationship between capital structure and the historical path of the marketto-book ratio. Section II discusses the results. Section III concludes. Additional robustness tests are included in the Appendix.

\section{Capital Structure and Past Market Valuations}

Prior research documents that individual financing decisions depend on market-to-book. Here we document the cumulative effect of the history of market-to-book ratios on capital structure. The main questions here are whether market-to-book affects capital structure through net equity issues, as market timing implies, and whether market-to-book has persistent effects that help to explain the cross section of leverage.

\section{A. Data and Summary Statistics}

Our main sample consists of COMPUSTAT firms for which we could determine the IPO date. Knowing the IPO date allows us to examine the behavior of leverage around the IPO, which is itself an important financing decision that is known to be related to the market-to-book ratio. Knowing the IPO date also allows us to study the evolution of leverage from a fixed starting point.

To form the main sample, we start with all COMPUSTAT firms appearing at any point between 1968 and 1999. We restrict this sample to firms for which we could determine an IPO date between 1968 and 1998. IPO dates are kindly provided by Jay Ritter for 1968 to 1995 issues and by the Securities Data Company for 1970 to 1998 issues. We use the SDC data where information is not available in the Ritter data. The Ritter and SDC data identify the subset of COMPUSTAT firms that went public within our sample period. We then officially define the IPO year as the first year in which COMPUSTAT reports market value data. We further restrict the sample to exclude financial firms with an SIC code between 6000 and 6999, firms with a minimum book value of assets below $\$ 10$ million, and firms without complete data on total assets between the IPO year and the year the firm exits COMPUSTAT. We further restrict the sample to exclude individual firm-year outliers for capital structure and the market-to-book ratio as discussed below. 
We typically study this sample in IPO time, meaning that we study it in subsamples that hold the number of years since the IPO constant. The whole sample includes 2,839 observations on firms at the first fiscal year end after IPO, 2,652 observations on firms in the next fiscal year (which we refer to as subsample IPO + 1), et cetera, down to 715 observations on firms at 10 years after the IPO (subsample IPO + 10). The steady attrition in IPO time is due to merger, bankruptcy, the end of all data in 1999, and other circumstances that cause an exit from COMPUSTAT. To be clear, each IPO $+k$ subsample includes only firms that have survived $k$ years from the IPO.

Panel A of Table I summarizes leverage and financing for this sample. We define book debt as total assets (COMPUSTAT Annual Item 6) minus book equity. We define book equity as total assets less total liabilities (Item 181) and preferred stock (Item 10) plus deferred taxes (Item 35) and convertible debt (Item 79). When preferred stock is missing, it is replaced with the redemption value of preferred stock (Item 56). Book leverage is then defined as book debt to total assets. We drop firm-year observations where the resulting book leverage is above one. ${ }^{4}$ We define market leverage as book debt divided by the result of total assets minus book equity plus market equity. Market equity is defined as common shares outstanding (Item 25) times price (Item 199). These definitions follow Fama and French (2000). The book leverage in the year prior to the IPO, which we call the pre-IPO value, is often available in COMPUSTAT.

Using the identity that book equity equals balance sheet retained earnings plus paid-in share capital, we define net equity issues $(e / A)$ as the change in book equity minus the change in balance sheet retained earnings (Item $36)$ divided by assets. We define newly retained earnings $(\Delta R E / A)$ as the change in retained earnings divided by assets. We define net debt issues $(d / A)$ as the residual change in assets divided by assets. ${ }^{5}$

Table I shows that, not surprisingly, book leverage decreases sharply following the IPO. Over the next 10 years, it rises slightly, while market value leverage rises more strongly. The book leverage trend is indeed an age effect, not a survival effect; the book leverage ratio for the subsample of firms that survive 10 years rises by a similar five percentage points (not reported). In terms of financing activity, the most notable result is the sharp switch to debt finance in the year following the IPO. This marks the transition to a

\footnotetext{
${ }^{4}$ The number of observations dropped depends on the sample being analyzed. In book values, this limit on leverage drops 47 firms from the IPO +1 sample and 28 firms in the IPO + 10 sample. Because market value cannot be less than zero, market leverage is never greater than one, so this limit has no effect on the market leverage samples.

${ }^{5}$ We have also defined equity and debt issues using cash flow statement data. Equity issues are the sale of common and preferred stock (Item 108) minus the purchase of common and preferred stock (Item 115), and debt issues are long-term debt issuance (Item 111) minus longterm debt reduction (Item 114) plus changes in current debt (Item 301). This made little difference to any of the results that follow. We prefer the balance sheet measures, because the statement of cash flows data is missing more often and start in 1971. The balance sheet measures are missing less often and are available for all COMPUSTAT firm-years.
} 
Table I

\section{Summary Statistics of Capital Structure and Financing Decisions}

Means and standard deviations of leverage and components of the change in assets. Book value leverage is book debt to assets and is expressed in percentage terms. In this and following tables, we drop firm-year observations where book leverage is above one. Market value leverage is book debt divided by the result of total assets minus book equity plus market equity and is expressed in percentage terms. Net equity issues $(e / A)$ are defined as the change in book equity, minus the change in retained earnings, divided by assets. Newly retained earnings $(\Delta R E / A)$ are defined as the change in retained earnings divided by assets. Net debt issues $(d / A)$ are defined as the residual change in assets divided by assets. The sample includes firm-year observations that satisfy data availability, nonfinancial industry, asset, and market-to-book screens. Panel A shows data in years relative to the IPO for firms with a known IPO date. Panel B shows data in calendar time for all COMPUSTAT firms.

\begin{tabular}{|c|c|c|c|c|c|c|c|c|c|c|c|}
\hline \multirow[b]{2}{*}{ Year } & \multirow[b]{2}{*}{$N$} & \multicolumn{2}{|c|}{ Book Leverage $D / A_{t} \%$} & \multicolumn{2}{|c|}{ Market Leverage $D / A_{t} \%$} & \multicolumn{2}{|c|}{$d / A_{t} \%$} & \multicolumn{2}{|c|}{$e / A_{t} \%$} & \multicolumn{2}{|c|}{$\Delta R E / A_{t} \%$} \\
\hline & & Mean & $S . D$. & Mean & S.D. & Mean & S.D. & Mean & $S . D$. & Mean & S.D. \\
\hline \multicolumn{12}{|c|}{ Panel A: IPO Time } \\
\hline Pre-IPO & 2,281 & 66.54 & $(21.33)$ & & & & & & & & \\
\hline IPO & 2,839 & 43.17 & $(21.41)$ & 27.18 & $(20.48)$ & 0.35 & $(20.89)$ & 32.98 & $(23.50)$ & 9.17 & $(19.08)$ \\
\hline $\mathrm{IPO}+1$ & 2,652 & 45.04 & $(21.80)$ & 32.78 & $(23.24)$ & 10.84 & (15.97) & 6.64 & $(14.56)$ & 2.68 & (13.98) \\
\hline $\mathrm{IPO}+3$ & 2,412 & 46.88 & $(21.44)$ & 40.30 & $(26.15)$ & 5.78 & $(16.22)$ & 3.93 & $(13.02)$ & 1.03 & $(14.90)$ \\
\hline $\mathrm{IPO}+5$ & 1,668 & 47.00 & (20.99) & 43.82 & $(26.59)$ & 3.53 & (15.33) & 3.07 & (11.28) & 1.10 & $(14.52)$ \\
\hline $\mathrm{IPO}+10$ & 715 & 48.68 & $(20.20)$ & 43.73 & $(24.85)$ & 4.32 & $(15.37)$ & 2.44 & $(9.28)$ & 1.21 & $(13.62)$ \\
\hline \multicolumn{12}{|c|}{ Panel B: Calendar Time, All Firms } \\
\hline 1970-1974 & 4,399 & 47.22 & $(17.92)$ & 51.11 & (22.79) & 4.84 & (11.91) & 0.98 & $(4.67)$ & 3.34 & $(6.57)$ \\
\hline 1975-1979 & 5,526 & 49.11 & (17.49) & 54.60 & $(22.27)$ & 4.58 & (12.38) & 0.66 & (3.79) & 4.09 & (6.77) \\
\hline 1980-1984 & 5,568 & 49.71 & (19.01) & 50.21 & $(23.84)$ & 3.45 & (13.54) & 1.70 & $(6.77)$ & 2.78 & (9.01) \\
\hline 1985-1989 & 6,441 & 49.44 & $(20.96)$ & 45.27 & $(24.31)$ & 3.97 & (17.51) & 2.11 & (9.68) & 1.22 & (12.31) \\
\hline 1990-1994 & 7,977 & 48.98 & (20.89) & 43.49 & (24.69) & 2.18 & (15.40) & 2.54 & (10.43) & 0.73 & (13.56) \\
\hline 1995-1999 & 11,165 & 49.01 & $(21.24)$ & 40.22 & $(24.83)$ & 4.54 & $(20.21)$ & 3.54 & (13.43) & 0.32 & (15.77) \\
\hline
\end{tabular}


steady pattern in average financing activity. Note that, under our definitions for financing activity, the change in assets is equal to the sum of net debt issues, net equity issues, and newly retained earnings. The table shows that on average, following the IPO, the annual change in assets is driven roughly 50 percent by net debt issues, 35 percent by net equity issues, and 15 percent by newly retained earnings. This is a broad generalization that hides wide cross-sectional variation, however, and indeed the change in assets is often negative.

For comparison with the IPO sample, Panel B studies the full 1970 to 1999 COMPUSTAT sample. This All Firms sample does not impose the known-IPOdate selection criterion. To be clear, the All Firms sample is a pooled firmcalendar year sample that contains multiple observations on the same firm and is analyzed as a single whole, not in subsamples that condition on survival; in contrast, the IPO $+k$ subsamples contain one observation per $k$-year-surviving firm. The All Firms sample also excludes financial firms, firms with missing data on assets or low book values, and individual firm-year outliers. Recent calendar trends in this sample include a decrease in market leverage, an increase in equity issues, and a decrease in internal finance. The decrease in market leverage reflects the historically high market valuations prevailing at the end of the 1990s. The concurrent increase in equity issues is suggestive of market timing. These trends also reflect the many newly public firms that appear near the end of the COMPUSTAT sample in 1999.

\section{B. Determinants of Annual Changes in Leverage}

Prior evidence on equity market timing notwithstanding, the net effect of market-to-book on changes in leverage is not obvious. Firms with high marketto-book ratios are often growing quickly and may be issuing as much debt as equity, for instance. Here we document the net effect of market-to-book on the annual change in leverage. Then we decompose the change in leverage to examine whether the effect comes through net equity issues, as market timing implies.

Our main focus is on market-to-book, but to round out a benchmark set of control variables, we also use three other variables that Rajan and Zingales (1995) find to be correlated to leverage in several developed countries. They are asset tangibility, profitability, and firm size. Market-to-book may be related to investment opportunities and market mispricing; we discuss this variable in much more detail after we document its relationship to leverage. It is defined as assets minus book equity plus market equity all divided by assets. We drop firm-year observations where market-to-book is greater than 10.0. Tangible assets may be used as collateral and so may be associated with higher leverage. Asset tangibility is defined as net plant, property, and equipment (Item 8) divided by total assets and expressed in percentage terms. Profitability is associated with the availability of internal funds and thus may be associated with less leverage under the pecking order theory. This relationship may also arise as a "neutral mutation" from the indifferent re- 
tention of earnings in a Modigliani and Miller environment, or from the tax-advantaged retention of earnings in a more realistic tax environment. Yet another hypothesis is that profitable firms face more free cash flow problems, in which case effective governance might call for more leverage (Jensen (1986)). Profitability is defined as earnings before interest, taxes, and depreciation (Item 13) divided by total assets and expressed in percentage terms. Size may increase leverage if large firms are less likely to enter financial distress. It is measured as the log of net sales (Item 12).

Table II explores the effects of these variables on annual changes in book leverage.

$$
\begin{aligned}
\left(\frac{D}{A}\right)_{t}-\left(\frac{D}{A}\right)_{t-1}= & a+b\left(\frac{M}{B}\right)_{t-1}+c\left(\frac{P P E}{A}\right)_{t-1}+d\left(\frac{E B I T D A}{A}\right)_{t-1} \\
& +e \log (S)_{t-1}+f\left(\frac{D}{A}\right)_{t-1}+u_{t} .
\end{aligned}
$$

We run this regression in IPO time on the IPO sample. For example, the IPO row in Panel A denotes the change in leverage between the pre-IPO value and the end of the IPO year; the IPO +1 row denotes the change in leverage from the end of the IPO year to the end of the IPO + 1 year; et cetera. The last variable, lagged leverage, is included because leverage is bounded between zero and one. When leverage is near one of these boundaries, the change in leverage can only go in one direction, regardless of the values of the other variables. Not controlling for lagged leverage may obscure the effects of the other variables. Lagged leverage therefore enters with a negative sign (not reported).

The more interesting results are as follows. The net effect of high marketto-book is to lower leverage. At IPO +3 , a one standard deviation increase in market-to-book is associated with a 1.14 percentage-point decrease in leverage. This is consistent with the idea that firms increase equity when market valuations are high, but it does not rule out a channel through higher retained earnings or lower debt, for example. The other columns show that tangible assets tend to increase leverage (by 0.69 percentage points per standard deviation increase), profitability tends to reduce leverage (by 1.40 percentage points per standard deviation increase), and size tends to increase leverage (by 0.95 percentage points per standard deviation increase). ${ }^{6}$ The results are generally consistent with theoretical priors. Fama-MacBeth calendar-time regressions on the All COMPUSTAT Firms sample yield no new conclusions and are omitted to save space.

\footnotetext{
${ }^{6}$ The comparative statics in this paragraph are computed with the coefficients in the IPO +3 row in Panel A of Table II and the sample standard deviations of the independent variables. $-1.14=-0.93 * 1.23$ where 1.23 is the standard deviation of lagged market-to-book at IPO $+3.0 .69=0.03 * 23.01$ where 23.01 is the standard deviation of lagged asset tangibility in percentage terms at IPO $+3 .-1.40=-0.10 * 14.02$ where 14.02 is the standard deviation of lagged profitability in percentage terms at IPO $+3.0 .95=0.69 * 1.37$ where 1.37 is the standard deviation of lagged log sales at IPO +3 .
} 
The other panels in Table II show how the change in leverage comes about. The change in leverage can be decomposed as follows:

$$
\begin{aligned}
\left(\frac{D}{A}\right)_{t}-\left(\frac{D}{A}\right)_{t-1} & =-\left[\left(\frac{E}{A}\right)_{t}-\left(\frac{E}{A}\right)_{t-1}\right] \\
& =-\left(\frac{e}{A}\right)_{t}-\left(\frac{\Delta R E}{A}\right)_{t}-\left[E_{t-1}\left(\frac{1}{A_{t}}-\frac{1}{A_{t-1}}\right)\right] .
\end{aligned}
$$

Equation (2) divides the change in leverage into equity issues, retained earnings, and the residual change in leverage, which depends on the total growth in assets from the combination of equity issues, debt issues, and newly retained earnings. In the bottom three panels in Table II, we regress each of these three components of changes in leverage on the market-to-book ratio and the other independent variables. This allows us to determine whether market-to-book affects leverage through net equity issues, as market timing implies.

The results indicate that the effect of market-to-book on changes in leverage does indeed come through net equity issues. Panel B shows that higher market-to-book is associated with higher net equity issues, consistent with the results of Marsh (1982) and others (note the sign of the dependent variable). Panel $\mathrm{C}$ shows that market-to-book is not strongly related to retained earnings, ruling out the possibility that market-to-book affects leverage because it forecasts earnings. Panel D shows that market-to-book is positively related to growth in assets, an effect that tends to increase leverage. This reflects the total effect of market-to-book on net equity issues, net debt issues, and newly retained earnings. ${ }^{7}$ By equation (2), the sum of the coefficients in Panels B, C, and D is equal to the total effect in Panel A. The clear result is that market-to-book affects leverage through net equity issues.

The other columns of Table II report results for asset tangibility, profitability, and size. Two interesting patterns are worth noting. First, the effect of profitability on changes in leverage arises primarily because of retained earnings. Profitable firms issue less equity, but this effect is more than offset by higher retained earnings, so that the net effect of higher profits is to reduce leverage. Second, firm size plays an important role at the time of the

\footnotetext{
${ }^{7}$ The coefficient in Panel D is positive, for the most part, because increasing the ratio of net equity issues to assets does not reduce leverage one for one. The derivative of the debt to assets ratio with respect to the ratio of net equity issues to assets is
}

$$
\frac{d}{d\left(\frac{e}{A}\right)_{t}}\left[\frac{D_{t}}{A_{t}}\right]=\frac{d}{d\left(\frac{e}{A}\right)_{t}}\left[\frac{D_{t}}{A_{t-1}+\left(\frac{e}{A}\right)_{t} A_{t}+\left(\frac{\Delta R E}{A}\right)_{t} A_{t}+\left(\frac{d}{A}\right)_{t} A_{t}}\right]=-\frac{D_{t}}{A_{t}} .
$$

Increasing the ratio of net equity issues to assets by $\epsilon$ therefore reduces leverage only by $D \epsilon / A$. 


\section{Table II}

\section{Determinants of Annual Changes in Leverage and Components}

OLS regressions of changes in book leverage and its components on the market-to-book ratio, fixed assets, profitability, firm size, and lagged leverage.

$$
\left(\frac{D}{A}\right)_{t}-\left(\frac{D}{A}\right)_{t-1}=-\left(\frac{e_{t}}{A_{t}}\right)-\left(\frac{\Delta R E_{t}}{A_{t}}\right)-\left[E_{t-1}\left(\frac{1}{A_{t}}-\frac{1}{A_{t-1}}\right)\right]=a+b\left(\frac{M}{B}\right)_{t-1}+c\left(\frac{P P E}{A}\right)_{t-1}+d\left(\frac{E B I T D A}{A}\right)_{t-1}+e \log (S)_{t-1}+f\left(\frac{D}{A}\right)_{t-1}+u_{t}
$$

We do not report $a$ and $f$. Book value leverage is book debt to assets and is expressed in percentage terms. The market-to-book ratio is assets minus book equity plus market equity all divided by assets and is measured at time $t-1$ except for the IPO year, when it is measured at time $t$. We drop firm-year observations where market-to-book is above 10. Fixed assets intensity is defined as net property, plant, and equipment divided by assets. Profitability is defined as operating income before depreciation, divided by assets. Firm size is defined as the log of net sales. The total change in leverage is in Panel A. The net equity issues component is in Panel B. The newly retained earnings component is in Panel C. The growth in assets component is in Panel D. Robust $t$-statistics are in parentheses.

\begin{tabular}{|c|c|c|c|c|c|c|c|c|c|c|}
\hline \multirow[b]{2}{*}{ Year } & \multirow[b]{2}{*}{$N$} & \multicolumn{2}{|c|}{$M / B_{t-1}$} & \multicolumn{2}{|c|}{$P P E / A_{t-1} \%$} & \multicolumn{2}{|c|}{$E B I T D A / A_{t-1} \%$} & \multicolumn{2}{|c|}{$\log (S)_{t-1}$} & \multirow[b]{2}{*}{$R^{2}$} \\
\hline & & $b$ & $t(b)$ & $c$ & $t(c)$ & $d$ & $t(d)$ & $e$ & $t(e)$ & \\
\hline \multicolumn{11}{|c|}{ Panel A: Change in Book Leverage $\left(\Delta(D / A)_{t}\right) \%$} \\
\hline IPO & 2,281 & -3.70 & $(-11.81)$ & 0.04 & $(2.50)$ & -0.10 & $(-3.84)$ & 3.83 & (14.65) & 0.45 \\
\hline $\mathrm{IPO}+1$ & 2,652 & -1.21 & $(-5.65)$ & 0.04 & (3.78) & -0.16 & $(-6.33)$ & 0.22 & (1.24) & 0.12 \\
\hline $\mathrm{IPO}+3$ & 2,412 & -0.93 & $(-4.47)$ & 0.03 & $(2.79)$ & -0.10 & $(-4.26)$ & 0.69 & $(4.31)$ & 0.08 \\
\hline $\mathrm{IPO}+5$ & 1,668 & -0.03 & $(-0.10)$ & 0.04 & (3.89) & -0.11 & $(-3.22)$ & 0.89 & $(5.09)$ & 0.06 \\
\hline $\mathrm{IPO}+10$ & 715 & -1.80 & $(-2.75)$ & 0.04 & $(2.20)$ & -0.02 & $(-0.28)$ & 0.12 & $(0.41)$ & 0.09 \\
\hline
\end{tabular}




\begin{tabular}{|c|c|c|c|c|c|c|c|c|c|c|}
\hline \multicolumn{11}{|c|}{ Panel B: Change in Book Leverage Due to Net Equity Issues $\left(-\left(e / A_{t}\right)\right) \%$} \\
\hline IPO & 2,281 & -5.33 & $(-13.58)$ & 0.05 & $(2.55)$ & 0.10 & (2.89) & 4.98 & (18.10) & 0.27 \\
\hline $\mathrm{IPO}+1$ & 2,652 & -3.44 & $(-11.76)$ & -0.02 & $(-1.55)$ & 0.31 & $(8.82)$ & 0.96 & (4.93) & 0.18 \\
\hline $\mathrm{IPO}+3$ & 2,412 & -3.69 & $(-10.87)$ & -0.01 & $(-1.05)$ & 0.25 & $(6.26)$ & 0.96 & $(3.80)$ & 0.17 \\
\hline $\mathrm{IPO}+5$ & 1,668 & -3.14 & $(-6.49)$ & 0.01 & $(0.54)$ & 0.20 & (3.68) & 0.73 & $(3.00)$ & 0.14 \\
\hline $\mathrm{IPO}+10$ & 715 & -3.56 & $(-4.41)$ & -0.02 & $(-1.22)$ & 0.25 & $(2.46)$ & 0.39 & (1.34) & 0.20 \\
\hline \multicolumn{11}{|c|}{ Panel C: Change in Book Leverage Due to Newly Retained Earnings $\left(-\left(\Delta R E / A_{t}\right)\right) \%$} \\
\hline IPO & 2,281 & 0.20 & $(0.59)$ & 0.02 & $(1.71)$ & -0.27 & $(-7.14)$ & 0.81 & (4.24) & 0.12 \\
\hline $\mathrm{IPO}+1$ & 2,652 & -0.18 & $(-0.80)$ & 0.01 & $(0.63)$ & -0.59 & $(-16.19)$ & -0.97 & $(-5.24)$ & 0.37 \\
\hline $\mathrm{IPO}+3$ & 2,412 & -0.20 & $(-0.54)$ & 0.03 & $(2.23)$ & -0.54 & $(-12.24)$ & -0.31 & $(-1.33)$ & 0.25 \\
\hline $\mathrm{IPO}+5$ & 1,668 & -0.51 & $(-0.77)$ & 0.01 & $(0.89)$ & -0.45 & $(-5.83)$ & -0.15 & $(-0.53)$ & 0.17 \\
\hline $\mathrm{IPO}+10$ & 715 & -0.37 & $(-0.41)$ & 0.05 & $(2.44)$ & -0.56 & $(-5.20)$ & -0.76 & $(-1.75)$ & 0.26 \\
\hline \multicolumn{11}{|c|}{ Panel D: Change in Book Leverage Due to Growth in Assets $\left(-E_{t-1}\left(1 / A_{t}-1 / A_{t-1}\right)\right) \%$} \\
\hline IPO & 2,281 & 1.44 & (6.68) & -0.02 & $(-2.91)$ & 0.07 & (3.24) & -1.96 & $(-12.79)$ & 0.46 \\
\hline $\mathrm{IPO}+1$ & 2,652 & 2.41 & (9.33) & 0.05 & (4.70) & 0.12 & $(3.31)$ & 0.24 & (1.15) & 0.16 \\
\hline $\mathrm{IPO}+3$ & 2,412 & 2.84 & $(9.82)$ & 0.01 & $(0.69)$ & 0.18 & (5.59) & 0.16 & $(0.65)$ & 0.13 \\
\hline $\mathrm{IPO}+5$ & 1,668 & 2.70 & $(6.50)$ & 0.00 & $(0.34)$ & 0.25 & $(4.78)$ & 0.47 & $(2.00)$ & 0.20 \\
\hline $\mathrm{IPO}+10$ & 715 & 1.77 & (3.84) & 0.01 & $(0.30)$ & 0.29 & (3.63) & 0.66 & $(2.06)$ & 0.17 \\
\hline
\end{tabular}


IPO. Panel A shows that the reduction in leverage that occurs at the IPO is much smaller for large firms. Panel B shows that this is because large firms issue less equity as a percentage of assets.

\section{Determinants of Leverage}

We have established that market-to-book affects leverage, in the short run, mainly through net equity issues. Whether or not this helps us to understand the cross section of leverage depends on persistence. Market timing could be just a local opportunism whose effect is quickly rebalanced away. Alternatively, if managers do not rebalance to some target leverage ratio, market timing may have persistent effects, and historical valuations will help to explain why leverage ratios differ. Whether one or the other alternative holds is an empirical question, which we address here.

We regress leverage on the Rajan and Zingales (1995) control variables and a variable that summarizes the relevant historical variation in market valuations. This is the "external finance weighted-average" market-to-book ratio. For a given firm-year, it is defined as

$$
\left(\frac{M}{B}\right)_{\text {efwa }, t-1}=\sum_{s=0}^{t-1} \frac{e_{s}+d_{s}}{\sum_{r=0}^{t-1} e_{r}+d_{r}} \cdot\left(\frac{M}{B}\right)_{s},
$$

where the summations are taken starting at the IPO year (or, in the All COMPUSTAT Firms sample, from the first year of COMPUSTAT data where stock price data are not missing), and $e$ and $d$ denote net equity and net debt issues, respectively, as defined earlier.

This variable takes high values for firms that raised external finance when the market-to-book ratio was high and vice-versa. The intuitive motivation for this weighting scheme is that external financing events represent practical opportunities to change leverage. It therefore gives more weight to valuations that prevailed when significant external financing decisions were being made, whether those decisions ultimately went toward debt or equity. This weighted average is better than a set of lagged market-to-book ratios because it picks out, for each firm, precisely which lags are likely to be the most relevant.

For purposes of computing this variable, we set the minimum weight to zero. We also drop firm-year observations where the resulting $M / B_{\text {efwa }}$ exceeds 10.0. ${ }^{8}$ The purpose of not allowing negative weights is to ensure that we are forming a weighted average. Otherwise the weights might not be increasing in the total amount of external finance raised in each period, which would eliminate the intuition that the weights correspond to times

\footnotetext{
8 The number of observations dropped depends on the sample being analyzed. In book leverage, this limit on market-to-book drops 27 firms in the IPO +1 tests and 1 firm in the IPO + 10 tests. We report results without this limit in a robustness check.
} 
when capital structure was most likely to be changed. In any event, a zero weight just means that the variable contains no information about the market valuation in that year. ${ }^{9}$

To compare the univariate explanatory power of this variable relative to other determinants of leverage, Figure 1 shows the $R^{2}$ for univariate regressions run in IPO time:

$$
\left(\frac{D}{A}\right)_{I P O+t}=a+b X_{t-1}+u_{t}
$$

where $X$ includes the four Rajan and Zingales (1995) variables, as well as four more variables used in a study of capital structure determinants by Fama and French (2000) that do not substantially overlap: two measures of dividends, a measure of depreciation, and a measure of research and development. Those variables are defined as follows. Dividends over book equity are common stock dividends (Item 21) divided by book equity. Dividends to market equity is self-explanatory. Depreciation expense to assets is depreciation (Item 14) divided by assets. Research and development to assets is R\&D expenditures (Item 46) divided by assets. Fama and French regard dividends to book equity as a proxy for profitability, dividends to market equity and research and development as proxies for investment opportunities, and depreciation as a proxy for nondebt tax shields. In analogy to our procedure with market-to-book, we also construct the weighted averages of the past values of each variable.

The solid lines in Figure 1 trace out the cross-sectional $R^{2}$ of $X_{t-1}$, and the dashed lines trace out the $R^{2}$ of $X_{\text {efwa,t-1 }}$. Panel A reports results for marketto-book. It enters with a negative coefficient, as expected. The weighted average explains about 15 percent of the cross-sectional variation in capital structure, and this cross-sectional explanatory power holds steady as firms age. In contrast, the explanatory power of the once-lagged value steadily diminishes as firms age. The growing gap between the dashed line and the solid line means that historical valuation information becomes increasingly relevant for firms that are more than a few years old.

The univariate explanatory power of the weighted average market-to-book is strong by comparison to the other variables. Both the weighted and the unweighted versions of asset tangibility have the expected positive coefficient but relatively low explanatory power. (We report the magnitude of the

\footnotetext{
${ }^{9}$ An alternative procedure that also ensures that the weight is increasing in the amount of external finance is to exclude years when the denominator (the sum of external finance from 0 to $t-1)$ is negative. This allows for some negative weights. Another possibility is to put all of the weight on the historical maximum market-to-book, that is, the maximum market-to-book that prevailed between the IPO and $t-1$. The intuition behind this measure is that if market valuations have large and persistent effects on leverage, this is most likely to be because of the extreme value. Other possibilities include an equal-weighted average and an external equityweighted average. All of these procedures give similar results and are omitted to save space.
} 
A. $M / B$

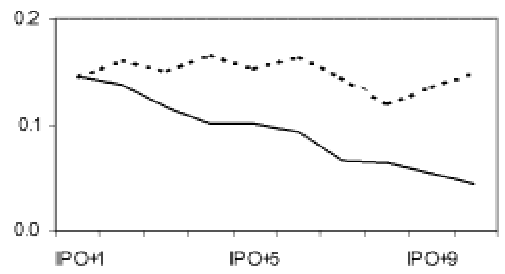

C. EBITDA/A

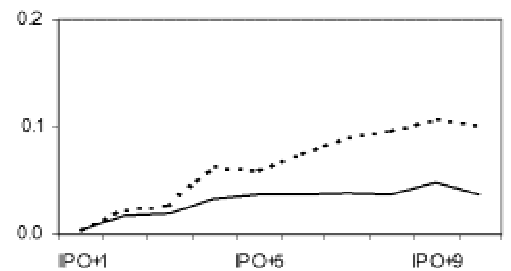

E. $D / B E$

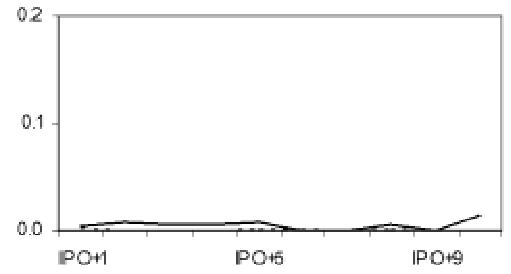

G. $D p / A$

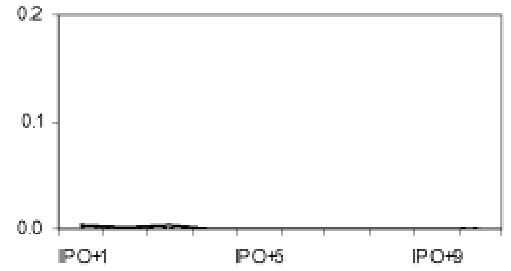

B. PPE/A

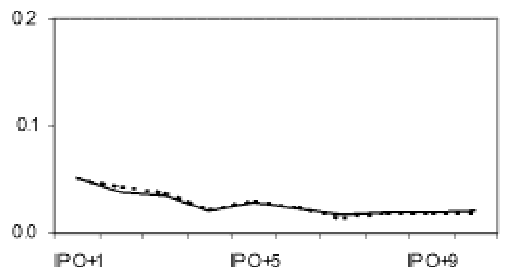

D. $\log (S)$

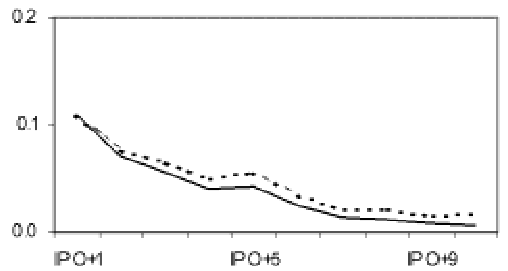

F. $D / M E$

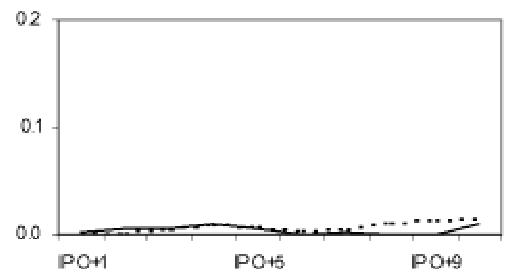

H. $R D / A$

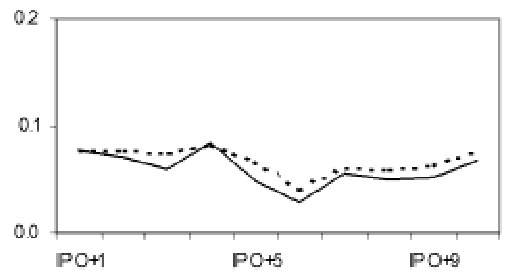

Figure 1. Univariate explanatory power of determinants of capital structure as corporations age. $R^{2}$ for univariate OLS regressions of book leverage on determinants of capital structure:

$$
\left(\frac{D}{A}\right)_{I P O+t}=a+b X_{t-1}+u_{t}
$$

Book value leverage is book debt to assets. We consider eight independent variables, and each one is defined in two ways. The solid line uses the year $t-1$ value. The dashed line uses an external finance weighted-average value from the IPO year through year $t-1$. External finance is defined as net equity issues plus net debt issues. Where this is negative, the weight is set to zero. Market-to-book is assets minus book equity plus market equity all divided by assets. We drop firm-year observations where market-to-book is above 10. Fixed assets intensity is defined as net property, plant, and equipment divided by assets. Profitability is defined as operating income before depreciation divided by assets. Firm size is defined as the log of net sales. Common dividends are scaled by book equity and market equity. Depreciation expense is scaled by assets. R\&D is defined as research and development expense divided by assets. 
coefficients in the multivariate results to follow.) Profitability has the expected negative coefficient and accumulates explanatory power as firms age, especially the weighted version. This makes sense if firms prefer to retain earnings rather than pay them out. The weighted average includes not only recent profitability but also the effect of past profitability, both of which affect total retained earnings. Size has the expected positive coefficient but relatively little ability to explain the cross section among firms that are more than a few years old. The two scaled dividends variables generally have positive coefficients, depreciation has an unstable coefficient, and none of these variables has a univariate $R^{2}$ consistently greater than 0.01 . This is perhaps not surprising in our sample of IPOs. Research and development expense has the expected negative coefficient and is stronger. Figure 1 also shows that the weighting scheme does not improve the performance of all variables. Historical information adds incremental value only to market-tobook and profitability. Finally, we note that survival bias does not drive the patterns in Figure 1. The same patterns are apparent in the sample of 10year survivors (not reported).

Figure 1 sheds new light on the dynamics of capital structure. It does not control for interrelationships-we do that shortly-but it does hint at some general conclusions. When firms go public, their capital structure reflects a number of factors, including market-to-book, asset tangibility, size, and research and development intensity. As firms age, the cross section of leverage is more and more explained by past financing opportunities, as determined by the market-to-book ratio, and past opportunities to accumulate retained earnings, as determined by profitability. The effect of past profitability has previously been noted by Titman and Wessels (1988).

Table III shows results for multivariate regressions of book and market leverage on the weighted average market-to-book ratio and the four Rajan and Zingales (1995) variables:

$$
\begin{aligned}
\left(\frac{D}{A}\right)_{t}= & a+b\left(\frac{M}{B}\right)_{\text {efwa }, t-1}+c\left(\frac{M}{B}\right)_{t-1}+d\left(\frac{P P E}{A}\right)_{t-1} \\
& +e\left(\frac{E B I T D A}{A}\right)_{t-1}+f \log (S)_{t-1}+u_{t} .
\end{aligned}
$$

The simultaneous inclusion of $M / B_{t-1}$ controls for current cross-sectional variation in the level of market-to-book. What is left for $M / B_{\text {efwa }}$ is the residual influence of past, within-firm variation in market-to-book. This is an important aspect of our experimental design. The first-order variation in market-to-book may be related to investment opportunities, not perceived mispricing. Controlling for current investment opportunities in the form of current market-to-book leaves the past within-firm variation to do a better job of picking up what may have been perceived as transient market timing opportunities. 
Table III

Determinants of Leverage

OLS and Fama-MacBeth regressions of book and market leverage on the market-to-book ratio, fixed assets, profitability, and firm size.

$$
\left(\frac{D}{A}\right)_{t}=a+b\left(\frac{M}{B}\right)_{\text {efwa }, t-1}+c\left(\frac{M}{B}\right)_{t-1}+d\left(\frac{P P E}{A}\right)_{t-1}+e\left(\frac{E B I T D A}{A}\right)_{t-1}+f \log (S)_{t-1}+u_{t} .
$$

We do not report $a$. Leverage is defined either as book debt to book assets (book value) or book debt to the result of total assets minus book equity plus market equity (market value) and is expressed in percentage terms. The market-to-book ratio is defined in two ways. The first is a weighted average market-to-book ratio from the IPO year to year $t-1$. The weights are the amount of external finance raised in each year. External finance is defined as net equity issues plus net debt issues. Where this is negative, the weight is set to zero. The second is the market-to-book ratio in year $t-1$, defined as assets minus book equity plus market equity all divided by assets. Fixed assets intensity is defined as net property, plant, and equipment divided by assets. Profitability is defined as operating income before depreciation divided by assets. Firm size is defined as the log of net sales. Panel A shows results for book leverage. Panel B shows results for market leverage. Robust $t$-statistics are in parentheses.

\begin{tabular}{|c|c|c|c|c|c|c|c|c|c|c|c|c|}
\hline \multirow[b]{2}{*}{ Year } & \multirow[b]{2}{*}{$N$} & \multicolumn{2}{|c|}{$M / B_{\text {efwa }, t-1}$} & \multicolumn{2}{|c|}{$M / B_{t-1}$} & \multicolumn{2}{|c|}{$P P E / A_{t-1} \%$} & \multicolumn{2}{|c|}{$E B I T D A / A_{t-1} \%$} & \multicolumn{2}{|c|}{$\log (S)_{t-1}$} & \multirow[b]{2}{*}{$R^{2}$} \\
\hline & & $b$ & $t(b)$ & $c$ & $t(c)$ & $d$ & $t(d)$ & $e$ & $t(e)$ & $f$ & $t(f)$ & \\
\hline \multicolumn{13}{|c|}{ Panel A: Book Leverage \% } \\
\hline $\mathrm{IPO}+1$ & 2,652 & & & -4.36 & $(-15.59)$ & 0.13 & $(7.30)$ & -0.22 & $(-6.44)$ & 5.00 & $(16.40)$ & 0.25 \\
\hline $\mathrm{IPO}+3$ & 2,412 & -4.93 & $(-8.40)$ & -0.86 & $(-1.50)$ & 0.12 & $(6.63)$ & -0.31 & $(-7.41)$ & 4.62 & $(15.53)$ & 0.25 \\
\hline $\mathrm{IPO}+5$ & 1,668 & -6.49 & $(-9.78)$ & 0.05 & $(0.07)$ & 0.12 & $(5.74)$ & -0.32 & $(-7.18)$ & 4.30 & $(12.40)$ & 0.26 \\
\hline $\mathrm{IPO}+10$ & 715 & -10.81 & $(-10.59)$ & 3.71 & $(3.23)$ & 0.12 & $(3.65)$ & -0.38 & $(-5.01)$ & 2.67 & $(4.82)$ & 0.23 \\
\hline 1980-1999 All firms & 31,151 & -7.21 & $(-21.20)$ & 2.20 & $(3.38)$ & 0.04 & $(3.62)$ & -0.48 & $(-7.20)$ & 2.84 & $(21.79)$ & 0.20 \\
\hline \multicolumn{13}{|c|}{ Panel B: Market Leverage \% } \\
\hline $\mathrm{IPO}+1$ & 2,694 & & & -8.09 & $(-26.57)$ & 0.14 & $(8.00)$ & -0.19 & $(-6.26)$ & 2.91 & $(9.96)$ & 0.36 \\
\hline $\mathrm{IPO}+3$ & 2,482 & -6.05 & $(-10.03)$ & -5.84 & $(-9.53)$ & 0.12 & $(6.53)$ & -0.32 & $(-9.17)$ & 3.31 & $(10.43)$ & 0.40 \\
\hline $\mathrm{IPO}+5$ & 1,731 & -7.41 & $(-9.55)$ & -5.30 & $(-6.14)$ & 0.12 & $(4.99)$ & -0.36 & $(-7.09)$ & 2.43 & $(6.25)$ & 0.37 \\
\hline $\mathrm{IPO}+10$ & 738 & -10.77 & $(-9.38)$ & -3.29 & $(-3.19)$ & 0.11 & $(3.22)$ & -0.53 & $(-5.92)$ & 1.23 & $(2.06)$ & 0.37 \\
\hline 1980-1999 All firms & 32,209 & -7.35 & $(-20.52)$ & -5.53 & $(-14.45)$ & 0.06 & $(3.65)$ & -0.61 & $(-7.54)$ & 1.63 & $(15.06)$ & 0.35 \\
\hline
\end{tabular}


Table III shows that the effect of $M / B_{\text {efwa }}$ is stronger and more consistent than $M / B_{t-1}$. This is especially true in book leverage, where $M / B_{t-1}$ does not benefit from a mechanical relationship to the dependent variable. In book values, the once-lagged market-to-book goes from having little incremental explanatory power for young firms, to none at all, then flips sign for older firms. In contrast, the coefficient on $M / B_{\text {efwa }}$ remains negative and actually gets larger with firm age. The importance of historical valuation information is also apparent in the 1980 to 1999 All Firms sample that does not impose the knownIPO date screen. For this sample, the weighted average is formed using marketto-book information from the first appearance on COMPUSTAT where stock price data are not missing (whether or not the firm appears in the SDC or Ritter IPO samples) through $t-1$. Overall, these results suggest that historical within-firm variation in market-to-book, not current cross-firm variation, is more important in explaining the cross section of leverage. This persistence of historical valuations contrasts with the normative trade-off theory in which managers keep leverage at a target determined by current characteristics.

Table III also indicates that the weighted average market-to-book is generally the single most economically important of these variables. At IPO +3 , for example, a one standard deviation increase in leverage is associated with a decrease in book leverage of 6.51 percentage points (e.g., from 46.88 percent, the IPO +3 sample mean, to 40.37 percent) and a decrease in market leverage of 7.99 percentage points. The second-largest effect at IPO +3 comes through size, where a one standard deviation increase in log sales is associated with an increase in book leverage of 6.33 percentage points and an increase in market leverage of 4.53 percentage points. As firms age, the effect of past market valuations becomes even more prominent, consistent with the impressions from Figure 1 . At IPO +10 , for example, a one standard deviation increase in $M / B_{\text {efwa }}$ is associated with a decrease in book leverage of 10.49 percentage points and a decrease in market leverage of 10.45 percentage points. The second-largest effect at IPO +10 comes through profitability, where a one standard deviation increase is associated with a decrease in book leverage of 4.59 percentage points and a decrease in market leverage of 6.40 percentage points. The relative strength of the effect of historical valuations is also large in the sample that does not condition on knowing the IPO date, indicating that the dynamics apparent in IPO time also apply to the broader COMPUSTAT universe. ${ }^{10}$

Table IV reports results of multivariate regressions that use the control variables suggested by Fama and French (2000). They use eight variables,

\footnotetext{
10 The comparative statics in this paragraph are computed as follows. Referring to the coefficients in Table III, $-6.51=-4.93 * 1.32$ and $-7.99=-6.05 * 1.32$, where 1.32 is the standard deviation of the lagged weighted average market-to-book at IPO $+3.6 .33=4.62 *$ 1.37 and $4.53=3.31 * 1.37$, where 1.37 is the standard deviation of lagged log sales at IPO $+3 .-10.49=-10.81 * 0.97$ and $-10.45=-10.77 * 0.97$, where 0.97 is the standard deviation of the lagged weighted average market-to-book at IPO $+10 .-4.59=-0.38 * 12.07$ and $-6.40=-0.53 * 12.07$ where 12.07 is the standard deviation of lagged profitability in percentage terms at IPO +10 .
} 
Table IV

\section{Determinants of Leverage: Alternative Control Variables}

OLS and Fama-MacBeth regressions of leverage on determinants suggested by Fama and French (2000).

$$
\begin{aligned}
\left(\frac{D}{A}\right)_{t}= & a+b\left(\frac{M}{B}\right)_{e f w a, t-1}+c\left(\frac{M}{B}\right)_{t-1}+d\left(\frac{E T}{A}\right)_{t-1}+e\left(\frac{D i v}{B E}\right)_{t-1}+f\left(\frac{D i v}{M E}\right)_{t-1}+g\left(\frac{D p}{A}\right)_{t-1} \\
& +h\left(\frac{R D}{A}\right)_{t-1}+i R D D_{t-1}+j \log (A)_{t-1}+u_{t} .
\end{aligned}
$$

We do not report $a$. Leverage is defined either as book debt to book assets (book value) or book debt to the result of total assets minus book equity plus market equity (market value) and is expressed in percentage terms. The market-to-book ratio is defined in two ways. The first is an external finance weighted average market-to-book ratio from the IPO year to year $t-1$. The weights are the amount of external finance raised in each year. External finance is defined as net equity issues plus net debt issues. Where this is negative, the weight is set to zero. The second is the market-to-book ratio in year $t-1$, defined as assets minus book equity plus market equity all divided by assets. Earnings before interest and taxes is scaled by assets. Common dividends are scaled by book equity and market equity. Depreciation expense is scaled by assets. Research and development expense is scaled by assets. RDD is a dummy set to one if the firm has no R\&D expense. Panel A shows results for book leverage. Panel B shows results for market leverage. Robust $t$-statistics are in parentheses. 


\begin{tabular}{|c|c|c|c|c|c|c|c|c|c|c|c|}
\hline & & $M / B_{e f w a}$ & $M / B$ & $E T / A \%$ & Div/BE \% & Div/ME\% & $D p / A \%$ & $R D / A \%$ & $R D D$ & $\log (A)$ & \\
\hline Year & $N$ & $\begin{array}{c}b \\
t(b)\end{array}$ & $\begin{array}{c}c \\
t(c)\end{array}$ & $\begin{array}{c}d \\
t(d)\end{array}$ & $\begin{array}{c}e \\
t(e)\end{array}$ & $\begin{array}{c}f \\
t(f)\end{array}$ & $\begin{array}{c}g \\
t(g)\end{array}$ & $\begin{array}{c}h \\
t(h)\end{array}$ & $\begin{array}{c}i \\
t(i)\end{array}$ & $\begin{array}{c}j \\
t(j)\end{array}$ & $R^{2}$ \\
\hline \multicolumn{12}{|c|}{ Panel A: Book Leverage $\%$} \\
\hline $\mathrm{IPO}+1$ & 2,651 & & $\begin{array}{c}-4.75 \\
(-16.83)\end{array}$ & $\begin{array}{l}-0.20 \\
(-5.89)\end{array}$ & $\begin{array}{c}0.31 \\
(6.92)\end{array}$ & $\begin{array}{l}-0.54 \\
(-5.19)\end{array}$ & $\begin{array}{c}0.06 \\
(0.78)\end{array}$ & $\begin{array}{l}-0.32 \\
(-3.50)\end{array}$ & $\begin{array}{c}7.35 \\
(6.88)\end{array}$ & $\begin{array}{c}3.83 \\
(12.22)\end{array}$ & 0.28 \\
\hline $\mathrm{IPO}+3$ & 2,411 & $\begin{array}{l}-4.46 \\
(-7.88)\end{array}$ & $\begin{array}{l}-0.36 \\
(-0.66)\end{array}$ & $\begin{array}{l}-0.35 \\
(-8.98)\end{array}$ & $\begin{array}{c}0.29 \\
(1.58)\end{array}$ & $\begin{array}{l}-0.16 \\
(-0.99)\end{array}$ & $\begin{array}{l}-0.08 \\
(-1.03)\end{array}$ & $\begin{array}{l}-0.45 \\
(-6.11)\end{array}$ & $\begin{array}{c}6.14 \\
(6.62)\end{array}$ & $\begin{array}{c}3.30 \\
(10.98)\end{array}$ & 0.29 \\
\hline $\mathrm{IPO}+5$ & 1,667 & $\begin{array}{l}-6.13 \\
(-9.02)\end{array}$ & $\begin{array}{c}0.25 \\
(0.35)\end{array}$ & $\begin{array}{l}-0.30 \\
(-8.17)\end{array}$ & $\begin{array}{c}0.28 \\
(2.58)\end{array}$ & $\begin{array}{l}-0.14 \\
(-1.07)\end{array}$ & $\begin{array}{l}-0.08 \\
(-1.08)\end{array}$ & $\begin{array}{l}-0.32 \\
(-2.45)\end{array}$ & $\begin{array}{c}5.32 \\
(4.25)\end{array}$ & $\begin{array}{c}3.25 \\
(9.46)\end{array}$ & 0.26 \\
\hline $\mathrm{IPO}+10$ & 715 & $\begin{array}{c}-9.45 \\
(-8.52)\end{array}$ & $\begin{array}{c}3.84 \\
(3.46)\end{array}$ & $\begin{array}{c}-0.44 \\
(-5.51)\end{array}$ & $\begin{array}{c}0.44 \\
(2.90)\end{array}$ & $\begin{array}{c}0.02 \\
(0.08)\end{array}$ & $\begin{array}{c}-0.17 \\
(-1.28)\end{array}$ & $\begin{array}{c}-0.42 \\
(-2.54)\end{array}$ & $\begin{array}{c}4.80 \\
(2.90)\end{array}$ & $\begin{array}{c}1.82 \\
(3.51)\end{array}$ & 0.27 \\
\hline 1980-1999 All firms & 31,147 & $\begin{array}{c}-6.28 \\
(-28.59)\end{array}$ & $\begin{array}{c}1.88 \\
(3.69)\end{array}$ & $\begin{array}{c}-0.43 \\
(-7.99)\end{array}$ & $\begin{array}{c}0.19 \\
(2.55)\end{array}$ & $\begin{array}{c}-0.48 \\
(-4.65)\end{array}$ & $\begin{array}{c}-0.31 \\
(-4.38)\end{array}$ & $\begin{array}{c}-0.52 \\
(-13.19)\end{array}$ & $\begin{array}{c}3.51 \\
(8.23)\end{array}$ & $\begin{array}{c}2.36 \\
(31.72)\end{array}$ & 0.22 \\
\hline \multicolumn{12}{|c|}{ Panel B: Market Leverage \% } \\
\hline $\mathrm{IPO}+1$ & 2,693 & & $\begin{array}{c}-7.66 \\
(-26.11)\end{array}$ & $\begin{array}{c}-0.22 \\
(-7.09)\end{array}$ & $\begin{array}{l}-0.04 \\
(-1.42)\end{array}$ & $\begin{array}{c}0.13 \\
(1.75)\end{array}$ & $\begin{array}{c}0.03 \\
(0.34)\end{array}$ & $\begin{array}{c}-0.48 \\
(-5.68)\end{array}$ & $\begin{array}{c}6.83 \\
(6.84)\end{array}$ & $\begin{array}{c}1.67 \\
(5.43)\end{array}$ & 0.39 \\
\hline $\mathrm{IPO}+3$ & 2,481 & $\begin{array}{l}-5.43 \\
(-8.95)\end{array}$ & $\begin{array}{l}-4.95 \\
(-8.05)\end{array}$ & $\begin{array}{l}-0.36 \\
(-9.82)\end{array}$ & $\begin{array}{l}-0.14 \\
(-1.18)\end{array}$ & $\begin{array}{c}0.42 \\
(3.28)\end{array}$ & $\begin{array}{l}-0.20 \\
(-2.67)\end{array}$ & $\begin{array}{l}-0.52 \\
(-5.63)\end{array}$ & $\begin{array}{c}7.18 \\
(6.70)\end{array}$ & $\begin{array}{c}1.67 \\
(5.23)\end{array}$ & 0.44 \\
\hline $\mathrm{IPO}+5$ & 1,730 & $\begin{array}{l}-6.53 \\
(-8.51)\end{array}$ & $\begin{array}{l}-4.52 \\
(-5.51)\end{array}$ & $\begin{array}{l}-0.36 \\
(-8.83)\end{array}$ & $\begin{array}{l}-0.06 \\
(-1.08)\end{array}$ & $\begin{array}{c}0.22 \\
(3.45)\end{array}$ & $\begin{array}{l}-0.22 \\
(-2.65)\end{array}$ & $\begin{array}{l}-0.60 \\
(-5.39)\end{array}$ & $\begin{array}{c}6.29 \\
(4.90)\end{array}$ & $\begin{array}{l}1.12 \\
(2.95)\end{array}$ & 0.40 \\
\hline $\mathrm{IPO}+10$ & 738 & $\begin{array}{l}-8.17 \\
(-6.50)\end{array}$ & $\begin{array}{l}-3.10 \\
(-2.91)\end{array}$ & $\begin{array}{c}-0.51 \\
(-6.85)\end{array}$ & $\begin{array}{c}-0.07 \\
(-0.37)\end{array}$ & $\begin{array}{c}0.33 \\
(0.70)\end{array}$ & $\begin{array}{l}-0.24 \\
(-1.95)\end{array}$ & $\begin{array}{c}-0.60 \\
(-3.53)\end{array}$ & $\begin{array}{c}6.15 \\
(3.47)\end{array}$ & $\begin{array}{c}0.13 \\
(0.24)\end{array}$ & 0.40 \\
\hline 1980-1999 All firms & 32,205 & $\begin{array}{c}-5.89 \\
(-20.76)\end{array}$ & $\begin{array}{c}-5.41 \\
(-12.02)\end{array}$ & $\begin{array}{l}-0.53 \\
(-9.50)\end{array}$ & $\begin{array}{l}-0.53 \\
(-2.86)\end{array}$ & $\begin{array}{c}0.17 \\
(1.29)\end{array}$ & $\begin{array}{l}-0.38 \\
(-5.43)\end{array}$ & $\begin{array}{c}-0.66 \\
(-14.17)\end{array}$ & $\begin{array}{c}4.51 \\
(8.27)\end{array}$ & $\begin{array}{c}1.34 \\
(11.07)\end{array}$ & 0.39 \\
\hline
\end{tabular}


some of which overlap with the variables used earlier. Their eight variables are: market-to-book, earnings before interest and taxes to assets, dividends over book equity, dividends to market equity, depreciation expense to assets, research and development expense to assets, a dummy variable for firms that report no research and development, and the log of total assets. As before, all independent variables are lagged. The results show that the coefficient on the weighted average market-to-book is not sensitive to this change in control variables. At IPO +10 , a one standard deviation change in $M / B_{\text {efwa }}$ is associated with bigger changes in book and market leverage than a similar one standard deviation change in the other independent variables (we omit the calculations for brevity). As before, the second-biggest effect is generally profitability. Overall, the results from Tables III and IV show that the effect of historical valuations on leverage is large and separate from various effects documented in prior literature. ${ }^{11}$

\section{Persistence}

So far we have documented two main results. First, high market valuations reduce leverage in the short run. Second, historically high market valuations are associated with lower leverage in the cross section. The connection between these two results must be that the market-to-book effect is very persistent. We conclude the empirical section by fleshing out the degree and magnitude of this persistence. We use the Rajan and Zingales (1995) control variables going forward. The results are similar using other controls.

Table $\mathrm{V}$ shows results for regressions of cumulative changes in leverage from the pre-IPO value on the Rajan and Zingales (1995) variables plus the pre-IPO value of leverage. ${ }^{12}$

11 The inclusion of a measure of the marginal corporate tax rate, kindly provided by John Graham as used in Graham, Lemmon, and Schallheim (1998), also did not affect the coefficient on the weighted average market-to-book.

12 The coefficients on $M / B_{\text {efwa,t-1 }}$ are slightly smaller when the initial level of leverage is not included as an independent variable. For example, the coefficient is -6.78 with a $t$-statistic of -3.45 for IPO +10 and book leverage. The reason for the reduced statistical and economic significance is that our sample contains firms that start with mostly debt or no debt. For these firms, the test is one-sided. It is impossible to increase leverage above 1 , and impossible to decrease leverage below 0 . The latter effect is more important for this sample. Unprofitable, all equity firms can issue lots of equity but cannot further reduce their leverage ratio in the face of high market valuations. By controlling for initial leverage, we can demonstrate that firms that start with low leverage and high valuations increase their leverage by less than firms that start out with similarly low leverage but low valuations. To us, this seems to be the relevant test. The coefficient on the initial level of leverage is not reported in Table V. It ranges from -0.62 to -0.71 for book value regressions and from -0.70 to -0.75 for market value regressions. 


\section{Table V}

\section{Determinants of Cumulative Changes in Leverage from the Pre-IPO Value}

OLS and Fama-MacBeth regressions of the cumulative change in leverage since the pre-IPO value on the market-to-book ratio, fixed assets, profitability, and firm size.

$$
\left(\frac{D}{A}\right)_{t}-\left(\frac{D}{A}\right)_{\text {pre-IPO }}=a+b\left(\frac{M}{B}\right)_{e f w a, t-1}+c\left(\frac{M}{B}\right)_{t-1}+d\left(\frac{P P E}{A}\right)_{t-1}+e\left(\frac{E B I T D A}{A}\right)_{t-1}+f \log (S)_{t-1}+g\left(\frac{D}{A}\right)_{p r e-I P O}+u_{t} .
$$

We do not report $a$ and $g$. Leverage is defined either as book debt to book assets (book value) or book debt to the result of total assets minus book equity plus market equity (market value) and is expressed in percentage terms. The market-to-book ratio is defined in two ways. The first is a weighted average market-to-book ratio from the IPO year to year $t-1$. The weights are the amount of external finance raised in each year. External finance is defined as net equity issues plus net debt issues. Where this is negative, the weight is set to zero. The second is the market-to-book ratio in year $t-1$, defined as assets minus book equity plus market equity all divided by assets. Fixed assets intensity is defined as net property, plant, and equipment divided by assets. Profitability is defined as operating income before depreciation divided by assets. Firm size is defined as the log of net sales. Panel A shows results for book leverage. Panel B shows results for market leverage. Robust $t$-statistics are in parentheses.

\begin{tabular}{|c|c|c|c|c|c|c|c|c|c|c|c|c|}
\hline \multirow[b]{2}{*}{ Year } & \multirow[b]{2}{*}{$N$} & \multicolumn{2}{|c|}{$M / B_{e f w a, t-1}$} & \multicolumn{2}{|c|}{$M / B_{t-1}$} & \multicolumn{2}{|c|}{$P P E / A_{t-1} \%$} & \multicolumn{2}{|c|}{$E B I T D A / A_{t-1} \%$} & \multicolumn{2}{|c|}{$\log (S)_{t-1}$} & \multirow[b]{2}{*}{$R^{2}$} \\
\hline & & $b$ & $t(b)$ & $c$ & $t(c)$ & $d$ & $t(d)$ & $e$ & $t(e)$ & $f$ & $t(f)$ & \\
\hline \multicolumn{13}{|c|}{ Panel A: Book Leverage \% } \\
\hline $\mathrm{IPO}+1$ & 2,166 & & & -4.10 & $(-13.43)$ & 0.11 & $(6.95)$ & -0.27 & $(-6.52)$ & 3.49 & $(12.44)$ & 0.46 \\
\hline $\mathrm{IPO}+3$ & 1,553 & -4.45 & $(-6.48)$ & -0.75 & $(-1.04)$ & 0.11 & $(5.34)$ & -0.36 & $(-6.25)$ & 3.45 & $(9.70)$ & 0.46 \\
\hline $\mathrm{IPO}+5$ & 1,058 & -5.46 & $(-6.73)$ & 0.03 & $(0.03)$ & 0.11 & $(4.33)$ & -0.36 & $(-7.35)$ & 3.58 & $(8.34)$ & 0.47 \\
\hline $\mathrm{IPO}+10$ & 381 & -10.26 & $(-6.96)$ & 4.25 & $(3.30)$ & 0.07 & $(1.82)$ & -0.28 & $(-3.54)$ & 2.34 & $(3.26)$ & 0.45 \\
\hline 1980-1999 All firms & 17,383 & -6.81 & $(-16.72)$ & 2.54 & $(5.03)$ & 0.05 & $(7.19)$ & -0.50 & $(-12.33)$ & 2.61 & $(14.34)$ & 0.48 \\
\hline \multicolumn{13}{|c|}{ Panel B: Market Leverage \% } \\
\hline $\mathrm{IPO}+1$ & 2,180 & & & -8.10 & $(-21.93)$ & 0.12 & $(6.98)$ & -0.27 & $(-7.33)$ & 1.57 & $(5.26)$ & 0.54 \\
\hline $\mathrm{IPO}+3$ & 1,588 & -5.47 & $(-7.70)$ & -5.68 & $(-7.87)$ & 0.12 & $(5.36)$ & -0.40 & $(-8.96)$ & 2.14 & $(5.41)$ & 0.53 \\
\hline $\mathrm{IPO}+5$ & 1,091 & -6.14 & $(-6.54)$ & -5.14 & $(-5.03)$ & 0.12 & $(4.18)$ & -0.39 & $(-5.86)$ & 1.59 & $(3.23)$ & 0.49 \\
\hline $\mathrm{IPO}+10$ & 393 & -11.78 & $(-8.29)$ & -1.96 & $(-1.76)$ & 0.09 & $(2.10)$ & -0.47 & $(-6.17)$ & 0.69 & $(0.91)$ & 0.56 \\
\hline 1980-1999 All firms & 17,896 & -6.74 & $(-14.81)$ & -6.25 & $(-6.40)$ & 0.08 & $(5.25)$ & -0.63 & $(-11.83)$ & 1.27 & $(7.93)$ & 0.55 \\
\hline
\end{tabular}




$$
\begin{aligned}
\left(\frac{D}{A}\right)_{t}-\left(\frac{D}{A}\right)_{\text {pre-IPO }}= & a+b\left(\frac{M}{B}\right)_{\text {efwa }, t-1}+c\left(\frac{M}{B}\right)_{t-1}+d\left(\frac{P P E}{A}\right)_{t-1} \\
& +e\left(\frac{E B I T D A}{A}\right)_{t-1}+f \log (S)_{t-1}+g\left(\frac{D}{A}\right)_{\text {pre-IPO }} \\
& +u_{t} .
\end{aligned}
$$

By measuring changes from the leverage prevailing in the year before the IPO, the dependent variable includes the effect of the IPO itself. This is useful for us because the IPO is a critical financing event known to be connected to market value.

Table $\mathrm{V}$ shows that the determinants of cumulative changes in leverage are essentially the same, in sign and magnitude, as the determinants of leverage levels reported in Table III. As before, a one standard deviation change in the weighted average market-to-book is associated with a larger change in the dependent variable than a similar one standard deviation change in other independent variables (we omit the calculations for brevity). This regression result indicates that the weighted average market-to-book result is unlikely to reflect an omitted firm characteristic that would also influence initial leverage. Instead, it provides more evidence that market valuations have effects on capital structure that persist and therefore accumulate over time.

Table VI takes a direct look at the persistence of the effect of past valuations. We test persistence with a system of three regressions. The first regression looks at the effect of $M / B_{\text {efwa, } t}$ on current capital structure at time $t+1$, controlling for other characteristics measured at time $t$. This is simply a repetition of the regressions in Table III. The second regression replaces current capital structure with future capital structure at time $t+\tau$, still using controls from time $t$. The third regression looks at the effect of $M / B_{\text {efwa }}$ measured at time $t$ on future capital structure, controlling for future characteristics measured at time $t+\tau-1$.

$$
\begin{aligned}
\left(\frac{D}{A}\right)_{t+1}= & a_{1}+b_{1}\left(\frac{M}{B}\right)_{e f w a, t}+c_{1}\left(\frac{M}{B}\right)_{t}+d_{1}\left(\frac{P P E}{A}\right)_{t}+e_{1}\left(\frac{E B I T D A}{A}\right)_{t} \\
& +f_{1} \log (S)_{t}+u_{1, t+1} \\
\left(\frac{D}{A}\right)_{t+\tau}= & a_{2}+b_{2}\left(\frac{M}{B}\right)_{e f w a, t}+c_{2}\left(\frac{M}{B}\right)_{t}+d_{2}\left(\frac{P P E}{A}\right)_{t}+e_{2}\left(\frac{E B I T D A}{A}\right)_{t} \\
& +f_{2} \log (S)_{t}+u_{2, t+\tau} \\
\left(\frac{D}{A}\right)_{t+\tau}= & a_{3}+b_{3}\left(\frac{M}{B}\right)_{e f w a, t}+c_{3}\left(\frac{M}{B}\right)_{t+\tau-1}+d_{3}\left(\frac{P P E}{A}\right)_{t+\tau-1} \\
& +e_{3}\left(\frac{E B I T D A}{A}\right)_{t+\tau-1}+f_{3} \log (S)_{t+\tau-1}+u_{3, t+\tau} .
\end{aligned}
$$


The trade-off theory with adjustment costs allows capital structure to respond slowly to $M / B_{t}$. But eventually the past, temporary fluctuations captured in $M / B_{\text {efwa }}$ measured at time $t$ should no longer matter. In terms of the coefficients, the trade-off theory predicts that $b_{2}$ and $b_{3}$ should be zero for capital structure measured in the distant future. The ratio of $b_{2}$ to $b_{1}$ and the ratio of $b_{3}$ to $b_{1}$ therefore measure the long-term effect of temporary fluctuations in the market-to-book ratio. By simultaneously estimating equation (7), we can also put confidence intervals around the two ratios.

Table VI reports the results. The columns on the left report FamaMacBeth estimates and $t$-statistics for $b_{1}, b_{2}, b_{3}$, and $c_{3}$. We require that the set of firms is the same in all three regressions. In other words, to be included in the first regression, a firm must survive at least $\tau$ years. As a result, the estimates of $b_{1}$ change with $\tau$. The first and second columns show that this survival effect is small. In book values, the coefficients fall in a narrow range between -6.91 and -7.48 . Note also that the first row in each panel matches the estimate for the 1980 to 1999 All Firms sample in Table III. The next four columns document the persistence of the $M / B_{\text {efwa }}$ effect: $b_{2}$ and $b_{3}$ both remain strongly significant for at least 10 years. ${ }^{13}$ The $b_{3}$ coefficient is surprising. Its strength indicates that marketto-book variation from 1990 and before, for example, remains a strong determinant of capital structure as of 2000. This is true controlling for the 1999 values of market-to-book and other characteristics. Perhaps even more surprising is that, in book values, $b_{3}$ is several times the size of the $c_{3}$ coefficients reported in the next two columns. Thus the historical path of market-to-book, even calculated with data over 10 years old, is much more influential than the current market-to-book. In market values, $b_{3}$ is also substantial relative to $c_{3}$, which is notable since much of the contemporaneous correlation between market-to-book and market leverage is likely to be mechanical.

The last columns in Table VI report the fraction of the initial effect that remains after $\tau$ years. For book leverage, $b_{2}$ divided by $b_{1}$ is still 0.73 after 10 years; 73 percent of the initial effect is still apparent 10 years later. By any practical definition, the effect is permanent. We also report a lower bound estimate of this ratio, calculated by drawing values of $b_{1}$ and $b_{2}$ from the joint distribution of the two estimates. We can say with 95 percent confidence that at least two-thirds of the $M / B_{\text {efwa }}$ effect lasts for 10 years. For market leverage, the effect is 100 percent permanent. The last two columns show similar results for the ratio of $b_{3}$ to $b_{1}$.

In summary, we have documented that historical market valuations have large and very persistent effects on capital structure. This effect is independent of various control variables. In the Appendix, we report results for some additional robustness checks.

13 The standard errors on $b_{3}$ are smaller than the standard errors on $b_{2}$ because the correlation between $M / B_{\text {efwa, } t}$ and $M / B_{t+\tau-1}$ is generally lower than correlation between $M / B_{\text {efwa,t }}$ and $M / B_{t}$. 
Table VI

Persistence of Market-to-Book Effects

Fama-MacBeth regressions of current and future leverage on the market-to-book ratio, fixed assets, profitability, and firm size.

$$
\begin{aligned}
& \left(\frac{D}{A}\right)_{t+1}=a_{1}+b_{1}\left(\frac{M}{B}\right)_{\text {efwa }, t}+c_{1}\left(\frac{M}{B}\right)_{t}+d_{1}\left(\frac{P P E}{A}\right)_{t}+e_{1}\left(\frac{E B I T D A}{A}\right)_{t}+f_{1} \log (S)_{t}+u_{1, t+1} \\
& \left(\frac{D}{A}\right)_{t+\tau}=a_{2}+b_{2}\left(\frac{M}{B}\right)_{e f w a, t}+c_{2}\left(\frac{M}{B}\right)_{t}+d_{2}\left(\frac{P P E}{A}\right)_{t}+e_{2}\left(\frac{E B I T D A}{A}\right)_{t}+f_{2} \log (S)_{t}+u_{2, t+\tau} \\
& \left(\frac{D}{A}\right)_{t+\tau}=a_{3}+b_{3}\left(\frac{M}{B}\right)_{\text {efwa }, t}+c_{3}\left(\frac{M}{B}\right)_{t+\tau-1}+d_{3}\left(\frac{P P E}{A}\right)_{t+\tau-1}+e_{3}\left(\frac{E B I T D A}{A}\right)_{t+\tau-1}+f_{3} \log (S)_{t+\tau-1}+u_{3, t+\tau} .
\end{aligned}
$$

We report only $b_{1}, b_{2}, b_{3}$, and $c_{3}$. Leverage is defined either as book debt to book assets (book value) or book debt to the result of total assets minus book equity plus market equity (market value) and is expressed in percentage terms. The persistence of the market-to-book effect is measured by a ratio of coefficients: $b_{2}$ divided by $b_{1}$ or $b_{3}$ divided by $b_{1}$. For each $\tau$ from 1 to 10 , we run a set of three regressions for each year $t$ starting $\tau$ years prior to 1980 and ending $s$ years prior to 1999 and record 20 sets of three coefficients. Only firms that survive $\tau$ years are included so that each set of coefficients is calculated with the same sample of firms. A lower bound estimate (LB) for the ratio of the

\begin{tabular}{|c|c|c|c|c|c|c|c|c|c|c|c|c|}
\hline \multirow[b]{2}{*}{ Year } & \multicolumn{6}{|c|}{$M / B_{\text {efwa }, t}$ Coefficient } & \multicolumn{2}{|c|}{$M / B_{t+\tau-1}$ Coefficient } & \multicolumn{4}{|c|}{ Coefficient Ratios and Lower Bounds } \\
\hline & $b_{1}$ & $t\left(b_{1}\right)$ & $b_{2}$ & $t\left(b_{2}\right)$ & $b_{3}$ & $t\left(b_{3}\right)$ & $c_{3}$ & $t\left(c_{3}\right)$ & $b_{2} / b_{1}$ & $L B_{p=0.05}$ & $b_{3} / b_{1}$ & $L B_{p=0.05}$ \\
\hline \multicolumn{13}{|c|}{ Panel A: Book Leverage \% } \\
\hline$t+1$ & -7.21 & $(-21.20)$ & -7.21 & $(-21.20)$ & -7.21 & $(-21.20)$ & 2.20 & (3.38) & 1.00 & - & 1.00 & - \\
\hline$t+3$ & -7.36 & $(-25.28)$ & -6.31 & $(-18.44)$ & -5.57 & $(-18.33)$ & 0.20 & $(0.29)$ & 0.86 & 0.81 & 0.76 & 0.71 \\
\hline$t+5$ & -7.48 & $(-24.85)$ & -5.99 & $(-14.98)$ & -5.35 & $(-16.97)$ & 0.24 & $(0.29)$ & 0.80 & 0.73 & 0.73 & 0.67 \\
\hline$t+10$ & -6.91 & $(-13.77)$ & -5.05 & $(-12.15)$ & -5.11 & $(-18.15)$ & 0.45 & $(0.49)$ & 0.73 & 0.66 & 0.75 & 0.68 \\
\hline \multicolumn{13}{|c|}{ Panel B: Market Leverage \% } \\
\hline$t+1$ & -7.35 & $(-20.52)$ & -7.35 & $(-20.52)$ & -7.35 & $(-20.52)$ & -5.53 & $(-14.45)$ & 1.00 & - & 1.00 & - \\
\hline$t+3$ & -7.50 & $(-19.34)$ & -7.51 & $(-13.33)$ & -6.64 & $(-18.64)$ & -7.72 & $(-19.33)$ & 1.00 & 0.90 & 0.90 & 0.81 \\
\hline$t+5$ & -7.65 & $(-19.04)$ & -7.61 & $(-12.57)$ & -6.13 & $(-18.26)$ & -8.57 & $(-16.92)$ & 1.00 & 0.89 & 0.82 & 0.75 \\
\hline$t+10$ & -6.47 & $(-9.59)$ & -6.98 & $(-13.56)$ & -5.67 & $(-14.36)$ & -9.23 & $(-13.25)$ & 1.08 & 0.98 & 0.88 & 0.74 \\
\hline
\end{tabular}
coefficients is calculated for the five percent level of significance by drawing from the joint distribution of the two means. Panel A shows results for book leverage. Panel B shows results for market leverage. Robust $t$-statistics are in parentheses. 


\section{Discussion}

We have documented that fluctuations in the market-to-book ratio have considerable and lasting effects on leverage. Here we ask whether the results can be explained by existing theories given particular interpretations of the market-to-book ratio. We also consider the possibility that capital structure evolves as the outcome of past attempts to time the market. In our opinion, the results are most consistent with this market-timing theory of capital structure.

\section{A. Trade-off Theory}

In perfect and efficient markets, Modigliani and Miller (1958) show that capital structure is irrelevant. The trade-off theory determines an optimal capital structure by adding various imperfections, including taxes, costs of financial distress, and agency costs, but retains the assumptions of market efficiency and symmetric information. Some of the imperfections that lead to an optimal trade-off are as follows. Higher taxes on dividends indicate more debt (Modigliani and Miller (1963) and Miller and Scholes (1978)). Higher nondebt tax shields indicate less debt (DeAngelo and Masulis (1980)). Higher costs of financial distress indicate more equity. Short of bankruptcy, senior debt can force managers to forgo profitable investment opportunities (Myers (1977)). Agency problems can call for more or less debt. Too much equity can lead to free cash flow and conflicts of interest between managers and shareholders (Jensen (1986)). Too much debt can lead to asset substitution and conflicts of interest between managers and bondholders (Fama and Miller (1972) and Jensen and Meckling (1976)). Harris and Raviv (1991) survey these and other possible influences on optimal capital structure.

The market-to-book ratio can be connected to several elements of the trade-off theory. It is most commonly attached to costly financial distress as in Myers (1977), Smith and Watts (1992), Rajan and Zingales (1995), and Barclay, Smith, and Watts (1995). The idea is that firms with substantial growth and investment opportunities have the most to lose when overhanging debt prevents new capital from being raised or leads to an inefficient bankruptcy negotiation during which some investment opportunities are forever lost.

The key testable prediction of the trade-off theory is that capital structure eventually adjusts to changes in the market-to-book ratio. The evidence indicates, however, that variation in the market-to-book ratio has a decades-long impact on capital structure (Table VI). In fact, past variation in market valuations is more important than several other variables suggested as determinants of the current optimum, including the current market valuation (Tables III and IV). One could argue that adjustment costs are so large, or deviating from the optimum involves such a small penalty, 
that adjustment within a 10-year span is not worthwhile. ${ }^{14}$ But our results make the point that a considerable fraction of cross-sectional variation in leverage has nothing to do with an optimum set by current characteristics.

\section{B. Pecking Order Theory}

In the pecking order theory described by Myers (1984), there is no optimal capital structure. To be more precise, if there is an optimum, the cost of deviating from it is insignificant in comparison to the cost of raising external finance. Raising external finance is costly because managers have more information about the firm's prospects than outside investors and because investors know this. In Myers and Majluf (1984), outside investors rationally discount the firm's stock price when managers issue equity instead of riskless debt. To avoid this discount, managers avoid equity whenever possible. The Myers and Majluf model predicts that managers will follow a pecking order, using up internal funds first, then using up risky debt, and finally resorting to equity. In the absence of investment opportunities, firms retain profits and build up financial slack to avoid having to raise external finance in the future.

The pecking order theory regards the market-to-book ratio as a measure of investment opportunities. With this interpretation in mind, both Myers (1984) and Fama and French (2000) note that a contemporaneous relationship between the market-to-book ratio and capital structure is difficult to reconcile with the static pecking order model. Iteration of the static version also suggests that periods of high investment opportunities will tend to push leverage higher toward a debt capacity. To the extent that high past marketto-book actually coincides with high past investment, however, our results suggest that such periods tend to push leverage lower. ${ }^{15}$

Myers (1984) suggests a more dynamic version in which high growth firms reduce leverage in order to avoid raising equity as investment opportunities arise in the future. Our results are also somewhat difficult to reconcile with this interpretation. Table II shows that high market-to-book firms reduce leverage through issuing equity, not through retaining earnings. Also, this version of the pecking order predicts a relationship between leverage and future investment opportunities. Our results control for current

\footnotetext{
${ }^{14} \mathrm{~A}$ second possibility is that past variation in the market-to-book ratio is itself a firm characteristic. A past average of market-to-book ratios may be more informative about investment opportunities than the current level of market-to-book. Put another way, the current level rather than the past average may represent a temporary fluctuation. The data do not support this explanation. Future investment is explained largely by the current market-to-book ratio, with the past weighted average entering with a negative sign. A table documenting this is available upon request.

${ }^{15}$ Helwege and Liang (1996) find that the probability of raising external finance is unrelated to the internal funds deficit, and that firms that could have obtained bank loans often choose to issue equity instead. This also contrasts with the static pecking order model.
} 
market-to-book and show that leverage is much more strongly determined by past values of market-to-book. ${ }^{16}$

\section{Managerial Entrenchment Theory}

In the dynamic theory of capital structure based on managerial entrenchment in Zwiebel (1996), high valuations and good investment opportunities facilitate equity finance, but at the same time allow managers to become entrenched. They may then refuse to raise debt to rebalance in later periods. This has a market-timing flavor, since managers issue equity when valuations are high and do not subsequently rebalance, but a very different interpretation. Managers are not attempting to exploit new investors. Rather, they are exploiting existing investors ex post by not rebalancing. Both views may be valid, and our results do not distinguish between them. As we discuss below, the first view gains support from the survey evidence and particularly from the evidence on earnings management and the long-run returns following equity issues and repurchases.

\section{Market Timing Theory}

We believe that a theory of capital structure based on market timing is the most natural explanation for our results. The theory is simply that capital structure evolves as the cumulative outcome of past attempts to time the equity market. To our knowledge, this theory of capital structure has not been articulated before.

There are two versions of equity market timing that lead to similar capital structure dynamics. The first is a dynamic form of Myers and Majluf (1984) with rational managers and investors and adverse selection costs that vary across firms or across time. Lucas and McDonald (1990) and Korajczyk, Lucas, and McDonald (1992) study adverse selection that varies across firms. Choe, Masulis, and Nanda (1993) study adverse selection that varies across time. Consistent with these stories, Korajczyk et al. (1991) find that firms tend to announce equity issues following releases of information, which may reduce information asymmetry. Also, Bayless and Chaplinsky (1996) find that equity issues cluster around periods of somewhat smaller announcement effects. To explain the results in this paper, these stories require that temporary fluctuations in the market-to-book ratio measure variations in adverse selection. If the costs of deviating from an optimal capital structure are small compared to the resulting variation in issuing costs, past variation in the market-to-book ratio can then have long-lasting effects as we observe.

The second version of equity market timing involves irrational investors (or managers) and time-varying mispricing (or perceptions of mispricing). Managers issue equity when they believe its cost is irrationally low and repurchase equity when they believe its cost is irrationally high. Market-to-

${ }^{16}$ See also Footnote 14. 
book is well known to be inversely related to future equity returns, and extreme values of market-to-book have been connected to extreme investor expectations by La Porta (1996), La Porta et al. (1997), Frankel and Lee (1998), and Shleifer (2000). If managers are trying to exploit too-extreme expectations, net equity issues will be positively related to market-to-book, which is the case empirically. If there is no optimal capital structure, managers need not reverse these decisions when the firm appears to be correctly valued and the cost of equity appears to be normal, leaving temporary fluctuations in market-to-book to have permanent effects on leverage.

It is important to keep in mind that this second version of market timing does not require that the market actually be inefficient. It does not ask managers to successfully predict stock returns. The critical assumption is simply that managers believe that they can time the market.

Our results do not discriminate between these two versions of market timing. Elements of each are present in the financing model of Stein (1996). In the survey by Graham and Harvey (2001), CFOs admit to trying to time the equity market, and two-thirds of those that have considered issuing common stock report that "the amount by which our stock is undervalued or overvalued" was an important consideration. This survey evidence supports the critical assumption in the market timing theory mentioned above-which is that managers believe they can time the market-but does not immediately distinguish between the mispricing and the dynamic asymmetric information version of market timing.

The evidence that distinctly supports the mispricing version comes from the low long-run stock returns following equity issues and the high long-run returns following repurchases. The magnitudes of these effects suggest that managers are, on average, successful at equity market timing. For example, Loughran and Ritter (1995) point out that the long-run abnormal returns to equity issuers, a rough measure of the magnitude of exploitable mispricing, are an order of magnitude bigger than the announcement effects of equity issues, a rough measure of the recognition of asymmetric information. The evidence in Baker and Wurgler (2000) suggests that equity issuers can, on average, also time the market component of the cost of equity. This makes the total gains to market timing even bigger in comparison to the adverse announcement effect, and suggests that outright mispricing is the primary motivation for equity market timing.

In summary, a range of evidence indicates that market timing is an important aspect of real financing decisions. Our results appear to support this view. Other interpretations cannot be completely ruled out, but we believe that the results are most naturally explained by the theory that leverage arises as the cumulative outcome of attempts to time the equity market.

\section{Conclusion}

In the traditional efficient and integrated capital markets world of Modigliani and Miller (1958), the costs of different forms of finance do not 
vary independently and therefore there is no gain from opportunistically switching among them. In contrast, a variety of evidence suggests that equity market timing is an important aspect of real financial policy. This evidence comes from analyses of actual financing decisions, analyses of longrun returns following equity issues and repurchases, analyses of realized and forecast earnings around equity issues, and surveys of managers.

In this paper, we trace the implications of equity market timing through to capital structure. We use the market-to-book ratio to measure the market timing opportunities perceived by managers. We find that low-leverage firms tend to be those that raised funds when their valuations were high, and conversely high-leverage firms tend to be those that raised funds when their valuations were low. We find that fluctuations in market valuations have large effects on capital structure that persist for at least a decade. These results are hard to understand within traditional theories of capital structure.

We believe the most realistic explanation for the results is that capital structure is largely the cumulative outcome of past attempts to time the equity market. In this theory, there is no optimal capital structure, so market timing financing decisions just accumulate over time into the capital structure outcome. This simple market timing theory of capital structure appears to have substantial explanatory power.

\section{Appendix}

Table AI presents six robustness tests. The left columns report the effect of $M / B_{\text {efwa }}$ on leverage using equation (5) as a model. The right columns report the effect of $M / B_{\text {efwa }}$ on changes in leverage using equation (6) as a model. The panels report results for different combinations of leverage measures (book or market) and samples (the IPO sample at IPO +10 or the All COMPUSTAT Firms sample).

The first three robustness tests (SIC-3 fixed effects, IPO-year fixed effects, Retained earnings) add various control variables. The fixed effects are self-explanatory. The retained earnings variable is the total retained earnings (Item 36) as of $t-1$, scaled by assets. Inclusion of this variable provides additional evidence that the $M / B_{\text {efwa }}$ effect comes through equity issues and not retained earnings. The next two robustness tests (Start $M / B=\operatorname{End} M / B$, Outliers included) use different samples. In Panel A for example, we consider firms that at IPO +10 had the same market-to-book value (within 0.5 in absolute value) as they had at the IPO. This controls for the "endpoint" valuations. The significance of the $M / B_{\text {efwa }}$ variable then reflects the fact that leverage depends on the path of market valuations between the IPO and today. The next row includes market-to-book outliers. Recall that in the earlier tables we exclude firm-year observations where $M / B_{t-1}$ or $M / B_{\text {efwa }}$ was greater than 10.0. The final robustness test uses a Tobit estimation to account for the censored dependent variable. Leverage is between zero and one and cumulative changes in leverage are between negative one and one. These robustness tests confirm earlier results. 


\section{Table AI}

\section{Determinants of Leverage and Cumulative Changes in Leverage from the Pre-IPO Level: Robustness Tests}

OLS and Fama-MacBeth regressions of leverage and the cumulative change in leverage from the preIPO level on the market-to-book ratio, fixed assets, profitability, and firm size. The leverage regressions use equation (5) as a model. The leverage changes regressions use equation (6) as a model. Other independent variables are included as indicated. We report only the coefficient on the weighted average market-to-book. Leverage is defined as book debt to book assets (book value) or book debt to the result of total assets minus book equity plus market equity (market value) and is expressed in percentage terms. The weighted average market-to-book ratio is the average market-to-book ratio between the IPO year to year $t-1$, weighted by the amount of external finance raised in each year. External finance is defined as net equity issues plus net debt issues. Where this is negative, the weight is set to zero. Three types of robustness tests are described in the Appendix. The first set (SIC-3 fixed effects, IPO-year fixed effects, retained earnings) add additional controls. The retained earnings variable is the total retained earnings as of $t$, scaled by assets. The second $\operatorname{set}(\operatorname{start} M / B=\operatorname{end} M / B$, outliers included) uses different initial samples. We consider firms that at IPO +10 had the same marketto-book (within 0.5 in absolute value) as at the IPO. We also consider firms with market-to-book outliers. The third set (Tobit) uses an alternative estimation approach. Panels A (book value) and C (market value) use firms that had IPOs 10 years earlier. Panels B (book value) and D (market value) use all firms with COMPUSTAT data between 1980 and 1999. Robust $t$-statistics are in parentheses.

\begin{tabular}{|c|c|c|c|c|c|c|c|c|}
\hline & \multicolumn{4}{|c|}{ Leverage Level } & \multicolumn{4}{|c|}{ Leverage Change from Pre-IPO } \\
\hline & $N$ & $b$ & $t(b)$ & $R^{2}$ & $N$ & $b$ & $t(b)$ & $R^{2}$ \\
\hline \multicolumn{9}{|c|}{ Panel A: Book Leverage $\%$, IPO +10} \\
\hline SIC-3 fixed effects & 715 & -8.55 & $(-6.45)$ & 0.45 & 381 & -10.54 & $(-4.80)$ & 0.69 \\
\hline IPO-year fixed effects & 715 & -10.82 & $(-9.59)$ & 0.26 & 381 & -9.77 & $(-6.10)$ & 0.48 \\
\hline Retained earnings & 703 & -10.53 & $(-9.80)$ & 0.32 & 379 & -9.78 & $(-6.32)$ & 0.53 \\
\hline Start $M / B=$ End $M / B$ & 299 & -21.26 & $(-5.83)$ & 0.31 & 168 & -24.48 & $(-6.01)$ & 0.52 \\
\hline Outliers included & 716 & -10.58 & $(-10.39)$ & 0.23 & 381 & -10.26 & $(-6.96)$ & 0.45 \\
\hline Tobit & 715 & -10.81 & $(-10.29)$ & - & 381 & -10.26 & $(-7.06)$ & - \\
\hline \multicolumn{9}{|c|}{ Panel B: Book Leverage \%, 1980-1999 All Firms } \\
\hline SIC-3 fixed effects & 31,151 & -6.46 & $(-17.69)$ & 0.39 & 17,383 & -6.10 & $(-15.46)$ & 0.64 \\
\hline IPO-year fixed effects & 31,151 & -7.43 & $(-21.11)$ & 0.22 & 17,383 & -6.49 & $(-16.23)$ & 0.50 \\
\hline Retained earnings & 30,762 & -6.43 & $(-15.71)$ & 0.33 & 17,272 & -6.30 & $(-14.80)$ & 0.54 \\
\hline Start $M / B=$ End $M / B$ & 17,149 & -8.51 & $(-11.19)$ & 0.18 & 9,822 & -9.08 & $(-8.60)$ & 0.46 \\
\hline Outliers included & 31,243 & -6.93 & $(-18.11)$ & 0.20 & 17,428 & -6.49 & $(-15.41)$ & 0.48 \\
\hline Tobit & 31,151 & -7.21 & $(-21.20)$ & - & 17,383 & -6.81 & $(-16.72)$ & - \\
\hline \multicolumn{9}{|c|}{ Panel C: Market Leverage \%, IPO + 10} \\
\hline SIC-3 fixed effects & 738 & -7.78 & $(-5.19)$ & 0.55 & 393 & -11.24 & $(-5.20)$ & 0.73 \\
\hline IPO-year fixed effects & 738 & -10.51 & $(-8.76)$ & 0.43 & 393 & -11.06 & $(-6.75)$ & 0.59 \\
\hline Retained earnings & 726 & -10.35 & $(-8.29)$ & 0.40 & 391 & -10.70 & $(-6.82)$ & 0.57 \\
\hline Start $M / B=$ End $M / B$ & 312 & -17.95 & $(-3.58)$ & 0.39 & 175 & -21.88 & $(-5.42)$ & 0.56 \\
\hline Outliers included & 739 & -10.10 & $(-8.52)$ & 0.35 & 393 & -11.78 & $(-8.29)$ & 0.56 \\
\hline Tobit & 738 & -10.77 & $(-9.38)$ & - & 393 & -11.78 & $(-7.83)$ & - \\
\hline \multicolumn{9}{|c|}{ Panel D: Market Leverage \%, 1980-1999 All Firms } \\
\hline SIC-3 fixed effects & 32,209 & -6.10 & $(-17.45)$ & 0.51 & 17,896 & -5.82 & $(-14.18)$ & 0.69 \\
\hline IPO-year fixed effects & 32,209 & -7.71 & $(-19.71)$ & 0.37 & 17,896 & -6.59 & $(-14.70)$ & 0.57 \\
\hline Retained earnings & 31,803 & -5.73 & $(-19.46)$ & 0.42 & 17,779 & -5.73 & $(-12.03)$ & 0.58 \\
\hline Start $M / B=$ End $M / B$ & 17,679 & -5.77 & $(-6.87)$ & 0.33 & 10,098 & -5.97 & $(-4.40)$ & 0.55 \\
\hline Outliers included & 32,313 & -7.87 & $(-13.99)$ & 0.34 & 17,945 & -6.48 & $(-14.75)$ & 0.54 \\
\hline Tobit & 32,209 & -7.35 & $(-20.52)$ & - & 17,896 & -6.74 & $(-14.81)$ & - \\
\hline
\end{tabular}




\section{REFERENCES}

Asquith, Paul, and David W. Mullins, 1986, Equity issues and offering dilution, Journal of Financial Economics 15, 61-89.

Baker, Malcolm, and Jeffrey Wurgler, 2000, The equity share in new issues and aggregate stock returns, Journal of Finance 55, 2219-2257.

Barclay, Michael J., Clifford W. Smith, Jr., and Ross L. Watts, 1995, The determinants of corporate leverage and dividend policies, Journal of Applied Corporate Finance 7, 4-19.

Bayless, Mark, and Susan Chaplinsky, 1996, Is there a window of opportunity for seasoned equity issuance? Journal of Finance 51, 253-278.

Brav, Alon, and Paul A. Gompers, 1997, Myth or reality? The long-run underperformance of initial public offerings: Evidence from venture capital and nonventure capital-backed companies, Journal of Finance 52, 1791-1822.

Choe, Hyuk, Ronald Masulis, and Vik Nanda, 1993, Common stock offerings across the business cycle: Theory and evidence, Journal of Empirical Finance 1, 1-31.

DeAngelo, Harry, and Ronald Masulis, 1980, Optimal capital structure under corporate and personal taxation, Journal of Financial Economics 8, 3-29.

Denis, David J., and Atulya Sarin, 2001, Is the market surprised by poor earnings realizations following seasoned equity offerings? Journal of Financial and Quantitative Analysis 36, 169-193.

Eckbo, B. Espen, Ronald A. Masulis, and Oyvind Norli, 2000, Seasoned public offerings: Resolution of the "new issues puzzle," Journal of Financial Economics 56, 251-292.

Fama, Eugene F., 1998, Market efficiency, long-term returns, and behavioral finance, Journal of Financial Economics 49, 283-306.

Fama, Eugene F., and Merton H. Miller, 1972, The Theory of Finance (Holt, Rinehart and Winston, New York).

Fama, Eugene F., and Kenneth R. French, 2000, Testing tradeoff and pecking order predictions about dividends and debt, Working paper, University of Chicago.

Frankel, Richard, and Charles M. C. Lee, 1998, Accounting valuation, market expectation, and cross-sectional stock returns, Journal of Accounting \& Economics 25, 283-319.

Graham, John R., and Campbell R. Harvey, 2001, The theory and practice of corporate finance: Evidence from the field, Journal of Financial Economics 60, 187-243.

Graham, John R., Michael L. Lemmon, and James S. Schallheim, 1998, Debt, leases, taxes, and the endogeneity of corporate tax status, Journal of Finance 53, 131-162.

Harris, Milton, and Arthur Raviv, 1991, The theory of capital structure, Journal of Finance 39, $127-145$.

Helwege, Jean, and Nellie Liang, 1996, Is there a pecking order? Evidence from a panel of IPO firms, Journal of Financial Economics 40, 429-458.

Hovakimian, Armen, Tim Opler, and Sheridan Titman, 2001, The debt-equity choice, Journal of Financial and Quantitative Analysis 36, 1-24.

Ikenberry, David, Josef Lakonishok, and Theo Vermaelen, 1995, Market underreaction to open market share repurchases, Journal of Financial Economics 39, 181-208.

Jegadeesh, Narasimhan, 2000, Long-term performance of seasoned equity offerings: Benchmark errors and biases in expectations, Financial Management 9, 5-30.

Jensen, Michael C., 1986, Agency costs of free-cash-flow, corporate finance, and takeovers, American Economic Review 76, 323-329.

Jensen, Michael, and William Meckling, 1976, Theory of the firm: Managerial behavior, agency costs and ownership structure, Journal of Financial Economics 3, 305-360.

Jung, Kooyul, Yong Cheol Kim, and Rene M. Stulz, 1996, Timing, investment opportunities, managerial discretion, and the security issue decision, Journal of Financial Economics 42, $159-185$.

Korajczyk, Robert, Deborah Lucas, and Robert McDonald, 1991, The effects of information releases on the pricing and timing of equity issues, Review of Financial Studies 4, 685-708.

Korajczyk, Robert, Deborah Lucas, and Robert McDonald, 1992, Equity issues with timevarying asymmetric information, Journal of Financial \& Quantitative Analysis 27, 397-417. 
La Porta, Rafael, 1996, Expectations and the cross section of stock returns, Journal of Finance 51, 1715-1742.

La Porta, Rafael, Josef Lakonishok, Andrei Shleifer, and Robert Vishny, 1997, Good news for value stocks: Further evidence on market efficiency, Journal of Finance 52, 859-874.

Loughran, Tim, and Jay Ritter, 1995, The new issues puzzle, Journal of Finance 50, 23-51.

Loughran, Tim, and Jay Ritter, 1997, The operating performance of firms conducting seasoned equity offerings, Journal of Finance 52, 1823-1850.

Loughran, Tim, Jay Ritter, and Kristian Rydqvist, 1994, Initial public offerings: International insights, Pacific-Basin Finance Journal 2, 165-199.

Lucas, Deborah, and Robert MacDonald, 1990, Equity issues and stock price dynamics, Journal of Finance 45, 1019-1043.

Marsh, Paul, 1982, The choice between equity and debt: An empirical study, Journal of Finance 37, 121-144.

Miller, Merton H., and Myron S. Scholes, 1978, Dividends and taxes, Journal of Financial Economics 6, 333-364.

Modigliani, Franco, and Merton H. Miller, 1958, The cost of capital, corporation finance, and the theory of investment, American Economic Review 48, 655-669.

Modigliani, Franco, and Merton H. Miller, 1963, Corporate income taxes and the cost of capital: A correction, American Economic Review 53, 433-443.

Myers, Stewart C., 1977, Determinants of corporate borrowing, Journal of Financial Economics 5, 147-175.

Myers, Stewart C., 1984, The capital structure puzzle, Journal of Finance 39, 575-592.

Myers, Stewart C., and Nicholas S. Majluf, 1984, Corporate financing and investment decisions when firms have information that investors do not have, Journal of Financial Economics 13, 187-221.

Pagano, Marco, Fabio Panetta, and Luigi Zingales, 1998, Why do companies go public? An empirical analysis, Journal of Finance 53, 27-64.

Rajan, Raghuram G., and Henri Servaes, 1997, Analyst following of initial public offerings, Journal of Finance 52, 507-529.

Rajan, Raghuram G., and Luigi Zingales, 1995, What do we know about capital structure? Some evidence from international data, Journal of Finance 50, 1421-1460.

Ritter, Jay, 1991, The long-run performance of initial public offerings, Journal of Finance 42, 365-394.

Shleifer, Andrei, 2000, Inefficient Markets: An Introduction to Behavioral Finance (Oxford University Press, Oxford).

Smith, Clifford W., and Ross L. Watts, 1992, The investment opportunity set and corporate financing, dividend, and compensation policies, Journal of Financial Economics 32, 263-292.

Speiss, D. Katherine, and John Affleck-Graves, 1995, Underperformance in long-run stock returns following seasoned equity offerings, Journal of Financial Economics 38, 243-267.

Stein, Jeremy C., 1996, Rational capital budgeting in an irrational world, Journal of Business $69,429-455$.

Stigler, George J., 1964, Public regulation of the securities markets, Journal of Business 37, $117-142$.

Taggart, Robert A., 1977, A model of corporate financing decisions, Journal of Finance 32, 1467-1484.

Teoh, Siew Hong, Ivo Welch, and T. J. Wong, 1998a, Earnings management and the long-run market performance of initial public offerings, Journal of Finance 53, 1935-1974.

Teoh, Siew Hong, Ivo Welch, and T. J. Wong, 1998b, Earnings management and the underperformance of seasoned equity offerings, Journal of Financial Economics 50, 63-99.

Titman, Sheridan, and Roberto Wessels, 1988, The determinants of capital structure choice, Journal of Finance 43, 1-19.

Zwiebel, Jeffrey, 1996, Dynamic capital structure under managerial entrenchment, American Economic Review 86, 1197-1215. 